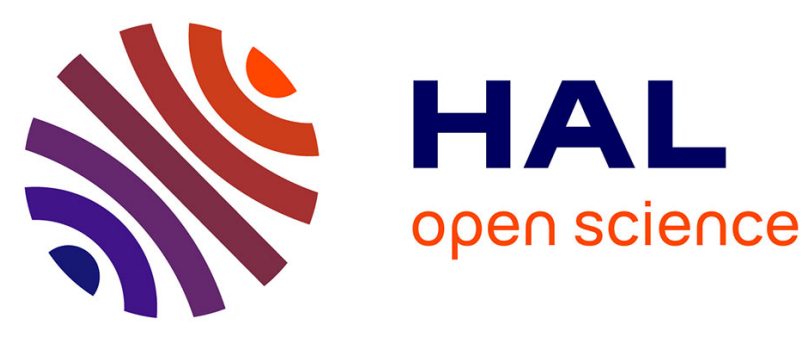

\title{
Synthesis, thermal properties, vibrational spectra and computational studies of Trioctylmethylammonium bis(trifluoromethylsulfonyl)imide ionic liquid
}

Mohammed Amin Assenine, Boumediene Haddad, Annalisa Paolone, Silvia Antonia Brandán, Mimanne Goussem, Didier Villemin, Mostefa Boumediene, Mustapha Rahmouni, Serge Bresson

\section{To cite this version:}

Mohammed Amin Assenine, Boumediene Haddad, Annalisa Paolone, Silvia Antonia Brandán, Mimanne Goussem, et al.. Synthesis, thermal properties, vibrational spectra and computational studies of Trioctylmethylammonium bis(trifluoromethylsulfonyl)imide ionic liquid. Journal of Molecular Structure, 2021, 1232, pp.130085. 10.1016/j.molstruc.2021.130085 . hal-03141770

\section{HAL Id: hal-03141770}

https://hal-normandie-univ.archives-ouvertes.fr/hal-03141770

Submitted on 15 Feb 2021

HAL is a multi-disciplinary open access archive for the deposit and dissemination of scientific research documents, whether they are published or not. The documents may come from teaching and research institutions in France or abroad, or from public or private research centers.
L'archive ouverte pluridisciplinaire HAL, est destinée au dépôt et à la diffusion de documents scientifiques de niveau recherche, publiés ou non, émanant des établissements d'enseignement et de recherche français ou étrangers, des laboratoires publics ou privés. 


\section{Synthesis, thermal properties, vibrational spectra and computational studies of Trioctylmethylammonium bis(trifluoromethylsulfonyl)imide ionic liquid}

Mohammed Amin Assenine ${ }^{1}$, Boumediene Haddad ${ }^{2,3,4,}{ }^{*}$, Annalisa Paolone ${ }^{5}$, Silvia Antonia Brandán ${ }^{6}$, Mimanne Goussem ${ }^{1}$, Didier Villemin ${ }^{3}$, Mostefa Boumediene ${ }^{2}$, Mustapha Rahmouni ${ }^{4}$, Serge Bresson ${ }^{7}$.

${ }^{1}$ Université Djillali Liabes, BP 89, 22000 Sidi-Bel-Abbes, Algeria

${ }^{2}$ Department of Chemistry, Faculty of Sciences, Dr Moulay Tahar University of Saïda, Algeria

${ }^{3}$ LCMT, ENSICAEN, UMR 6507 CNRS, University of Caen, 6 bd Ml Juin, 14050 Caen, France

${ }^{4}$ Synthesis and Catalysis Laboratory LSCT, Tiaret University, Tiaret, Algeria

${ }^{5}$ CNR-ISC, U.O.S. La Sapienza, Piazzale A. Moro 5, 00185 Roma, Italy

${ }^{6}$ Cátedra de Química General, Instituto de Química Inorgánica, Facultad de Bioquímica. Química y Farmacia, Universidad Nacional de Tucumán, Ayacucho 471, (4000) San Miguel de Tucumán, Tucumán, Argentina.

${ }^{7}$ Laboratoire de Physique des Systèmes Complexes, Université Picardie Jules Verne, 33 rue St Leu 80039 Amiens cedex, France.

* Corresponding author: Haddad Boumediene, Department of Chemistry, Faculty of Sciences, Dr Moulay Tahar University of Saïda, Algeria.

E-mail: haddadboumediene@yahoo.com Tel.: +00213676802567 


\begin{abstract}
In this work, Aliquat 336 ([Aliquat $\left.{ }^{+}\right]$) based ionic liquids containing the fluorinated anion bis(trifluoromethylsulfonyl)imide $\left[\mathrm{NTf}_{2}^{-}\right]$is successfully prepared by the anionic exchange replacement of the chloride anion. The reaction of lithium bis(trifluoromethylsulfonyl)imide with $N$-Methyl- $N, N, N$-trioctylammonium chloride $\left(\left[\mathrm{N}_{1,8,8,8}\right][\mathrm{Cl}]\right.$ in water leads to the corresponding IL, namely ([Aliquat $\left.{ }^{+}\right]\left[\mathrm{NTf}_{2}^{-}\right]$). The obtained ionic liquid was characterized by using infrared and Raman spectra and its structure was confirmed by ${ }^{1} \mathrm{H}-\mathrm{NMR},{ }^{13} \mathrm{C}-\mathrm{NMR}$, and ${ }^{19} \mathrm{~F}-\mathrm{NMR}$. The thermal properties were investigated by two complementary thermal analysis techniques: TGA and DTA. A hexadentate coordination mode between cation-anion was predicted by atoms in molecules (AIM) studies for the $\left[\right.$ Aliquat $\left.^{+}\right]\left[\mathrm{NTf}_{2}{ }^{-}\right]$IL by using B3LYP/6-31G* calculations where three $\mathrm{O}$ atoms of the anion are linked to six $\mathrm{H}$ atoms of cation by $\mathrm{S}-\mathrm{O} \cdots \mathrm{H}$ interactions. Changes in the bond orders of $\mathrm{S}$ and $\mathrm{O}$ atoms of the cation support such observations. The predicted cation-anion distances are in the range 2.30-2.60 $\AA$. The harmonic force fields of cation and anion were calculated and the complete assignments were performed for both species while the most important bands observed in the infrared and Raman spectra of the IL were assigned. In addition, the scaled force constants of cation and anion of the IL are also reported.
\end{abstract}

KEYWORDS: Aliquat 336; Trioctylmethylammonium; bis (trifluoromethylsulfonyl) imide; Thermal analysis; FTIR/Raman measurements; DFT calculations. 


\section{INTRODUCTION:}

Investigations on ionic liquids have increased remarkably in recent times due to their versatile physical-chemical properties which include very low vapor pressure, liquid state at room temperature, non-flammability, high solubility power, good solvent capacity and their potential as designer solvents for catalytic, chemical applications and in processes relating to transport and storage of energy [1-9]. Ionic liquids (ILs) such as, imidazolium, pyridinium, ammonium, pyrrolidinium were investigated as potential candidates for many applications [10-13], e.g. as efficient corrosion inhibitors for several metals and alloys [14]. In particular, the tetraalkylammonium salts $\left[\mathrm{C}_{\mathrm{i}} \mathrm{C}_{\mathrm{j}} \mathrm{C}_{\mathrm{k}} \mathrm{C}_{\mathrm{l}} \mathrm{N}\right]^{+}$(with $\mathrm{i}, \mathrm{j}, \mathrm{k}, 1$ referring to number of carbon atoms in alkyl chains) have evidenced good corrosion inhibition properties compared with their heterocyclic analogues [15]. In this sense, Aliquat 336, also known as $\left(\left[\mathrm{N}_{1,8,8,8}\right][\mathrm{Cl}]\right)$ or $N$ Methyl- $N, N, N$-trioctylammonium or tricaprylmethylammonium, is a quaternary ammonium salt that exhibits quite unusual and distinctive properties with major applications, such as phase transfer catalysis, lubrication, metal extraction, and removal of metals from hydrochloric acid solutions [16-21]. Besides, Aliquat 336 is more stable against air and moisture attack than other cationic ligands and it is easy to handle [22]. A great advantage is that the synthesis reactions of Aliquat ionic liquids are more environmentally benign and friendly [23]. Hence, the preparation and properties of this family are a rapidly growing area of research interest [24-26]. Mikkola et al. have reported that the use of Aliquat 336 in many chemical reactions could be limited due to the strong coordination effect of the chloride anion [27]. Hence, the cation-anion interaction in ionic liquids is a key factor determining the physico-chemical properties of ILs [28,29]. The design of new ILs with anions different from $\mathrm{Cl}^{-}$could provide interesting physico-chemical properties and, for these reasons, the knowledge about the synthesis, the thermal and vibrational properties and interaction between coupled cation-anion in these ILs are important subjects. Studies on vibrational properties, intermolecular vibrations, molecular conformations, and hydrogen-bonded interactions are of great interest in ionic liquids [30-34]. Experimental techniques such as, infrared (IR) and Raman spectroscopies have provided new insights on ionic interactions and the resulting liquid structure in ionic liquids [35-38]. The combination of synthesis and spectroscopic properties with quantum chemistry calculations allows the elucidation of intra- and inter-ionic interactions in new ionic liquids [35-38]. Structural and vibrational studies of quaternary 
ammonium prepared from mono-, bi-, tri-, and tetra-alkylammonium cations combined with several anions have been reported by different authors [36, 39-49] but, so far, the complete assignments of FTIR and Raman spectra of Aliquat 336 have not been reported, yet. The present work focuses on the synthesis, characterization of the thermal and vibrational properties of a Aliquat based ionic liquid, namely Aliquat (bis(trifluoromethylsulfonyl) Imide) ([Aliquat $\left.{ }^{+}\right]\left[\mathrm{NTf}_{2}^{-}\right]$). This Aliquat ionic liquid has been synthesized and characterized by infrared and Raman spectroscopies being its structure confirmed by using ${ }^{1} \mathrm{H},{ }^{13} \mathrm{C}$ and ${ }^{19} \mathrm{~F}$ NMR spectroscopies. The interpretation of vibrational spectra performed using infrared (FTIR/ATR) and Raman spectroscopy and a detailed DFT investigation of ionic liquid was also performed. In this work, the cation and anion of the Aliquat based ionic liquid were also structural and vibrationally characterized.

\section{Experimental}

\subsection{Materials and methods}

The chemicals used in this study are $N$-Methyl- $N, N, N$-trioctylammonium chloride $(>99 \%)$ and lithium bis(trifluoromethylsulfonyl)imide (99\%). They were purchased from Aldrich and used as received. Deionized $\mathrm{H}_{2} \mathrm{O}$ was obtained with a Millipore ion-exchange resin deionizer.

\subsection{General procedure for the synthesis of Aliquat $336 \mathrm{IL}$}

Firstly, the quaternary ammonium salt $\left(\left[\right.\right.$ Aliquat $\left.\left.^{+}\right]\left[\mathrm{Cl}^{-}\right]\right)$is obtained commercially and was used as received. The reaction of lithium bis(trifluoromethylsulfonyl)imide with $N$-Methyl$\mathrm{N}, \mathrm{N}, \mathrm{N}$-trioctylammonium chloride in water leads to the corresponding IL namely ([Aliquat $\left.{ }^{+}\right]$ $\left.\left[\mathrm{NTf}_{2}^{-}\right]\right)$. In detail, the synthesis of $\left(\left[\right.\right.$Aliquat $\left.\left.^{+}\right]\left[\mathrm{NTf}_{2}^{-}\right]\right)$can be described as follows [50]. Lithium bis(trifluoromethylsulfonyl)imide $(2.87 \mathrm{~g}, 10 \mathrm{mmol})$ dissolved in $10 \mathrm{~mL}$ of deionized water was added in a flask containing $N$-Methyl- $N, N, N$-trioctylammonium chloride $(4.32 \mathrm{~g}$, $10 \mathrm{mmol}$ ) dissolved in $5 \mathrm{~mL}$ of deionized water. The mixture consisted of two separate phases: the ionic liquid at the bottom and an aqueous solution at the top. The former was separated from the latter by centrifugation $(2000 \mathrm{rpm})$ for 600 seconds. After isolation, the obtained [Aliquat $\left.{ }^{+}\right]\left[\mathrm{NTf}_{2}{ }^{-}\right]$was washed with distilled water several times to eliminate $\mathrm{LiCl}$ residues and was dried in phosphorus pentoxide, $\mathrm{P}_{2} \mathrm{O}_{5}$, to remove residual water. The obtained product is yellowish viscous liquids (Yield: 65\%). The removal of the chloride ions was followed by testing the aqueous solution by chloride precipitation using $\mathrm{AgNO}_{3}$. The obtained compounds 
were investigated by NMR in order to probe the desired structure (see next sub-section). The structure of the ionic liquid prepared and studied in the present work is shown in Scheme $\mathbf{1}$.

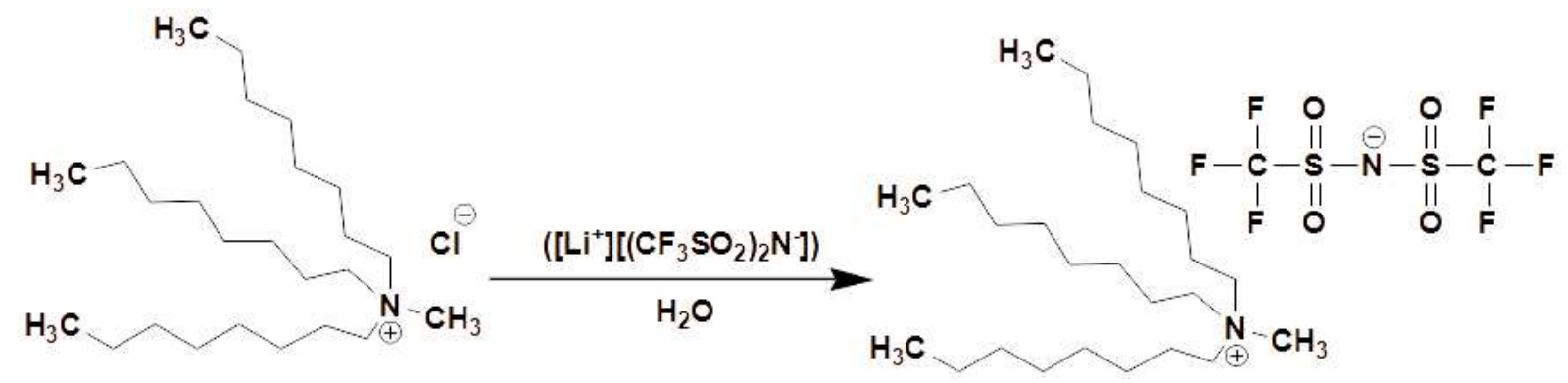

Scheme 1: The synthesis process of $\left(\left[\right.\right.$ Aliquat $\left.\left.^{+}\right]\left[\mathrm{NTf}_{2}{ }^{-}\right]\right)$.

\subsection{NMR analysis}

The structure and purity of the synthesized ionic liquid was confirmed by NMR analysis: ${ }^{1} \mathrm{H}-$ NMR (400 MHz) and ${ }^{13} \mathrm{C}-\mathrm{NMR}(100 \mathrm{MHz})$ spectra were recorded on a DRX $400 \mathrm{MHz}$ spectrometer $(400 \mathrm{MHz})$. The chemical shifts $(\delta)$ are given in ppm and referred to the internal solvent signal namely tetramethylsilane (TMS) and trichlorofluoromethane $\left(\mathrm{CFCl}_{3}\right)$.

\subsection{Thermal analysis}

Concomitant measurements of thermogravimetry (TGA) and differential thermal analysis (DTA) were performed by means of a Setaram Setsys Evolution 1200 TG System, with a fixed temperature rate of $5^{\circ} \mathrm{C} / \mathrm{min}$, in an argon flux of $60 \mathrm{ml} / \mathrm{min}$. For each sample, an initial mass of $\sim 20 \mathrm{mg}$ was used.

\subsection{Vibrational spectroscopy}

\subsubsection{FTIR/ATR measurements}

The FTIR/ATR measurements were acquired on a Bruker Vertex II-70RAM Spectrometer (Bruker Analytical, Madison, WI) operating with a Golden Gate diamond ATR accessory TM (Specac Ltd, Slough, United Kingdom). The FTIR/ATR spectra were collected with $1 \mathrm{~cm}^{-1}$ nominal resolution by co-adding 64 scans for each spectrum in the range $600-4000 \mathrm{~cm}^{-1}$. The OPUS Software 6.0 for Windows was used for the management of the instrument.

\subsubsection{FT-RAMAN measurements}


FT-Raman spectra were acquired on a Vertex 70-RAM II Bruker FT-Raman spectrometer. This instrument is equipped with a Nd:YAG laser (yttrium aluminium garnet crystal doped with triply ionized neodymium) with a wavelength of $1064 \mathrm{~nm}$ and a maximum power of 1.5 $\mathrm{W}$. The measurement accessory is pre-aligned: only the Z-axis of the scattered light is adjusted to set the sample in the appropriate position regarding the local measurement point. The RAM II spectrometer is equipped with a liquid nitrogen cooled Ge detector. FT-Raman spectra were collected with $1 \mathrm{~cm}^{-1}$ resolution by co-adding 128 scans for each spectrum at room temperature in the range $45-4000 \mathrm{~cm}^{-1}$. The OPUS 6.0 software was used for the spectral acquisition, manipulation and transformation. These both measurements FTIR/ATR and FTRAMAN were performed in the Walloon Agricultural Research Center (Craw) Belgium.

\section{Computational}

The Gauss View program was used to model the $\left[\mathrm{Aliquat}^{+}\right]\left[\mathrm{NTf}_{2}^{-}\right]$ionic liquid and its [Aliquat $\left.{ }^{+}\right]$cationic and $\left[\mathrm{NTf}_{2}^{-}\right]$anionic species [51] and, later the three structures were optimized in gas phase with the Revision A.02 of Gaussian 09 program [52] by using the functional hybrid B3LYP with the $6-31 \mathrm{G}^{*}$ basis set $[53,54]$. The structures of cation and anion are shown in Figure 1 while the corresponding [Aliquat $\left.{ }^{+}\right]\left[\mathrm{NTf}_{2}^{-}\right.$] ionic liquid can be seen in Figure 2.

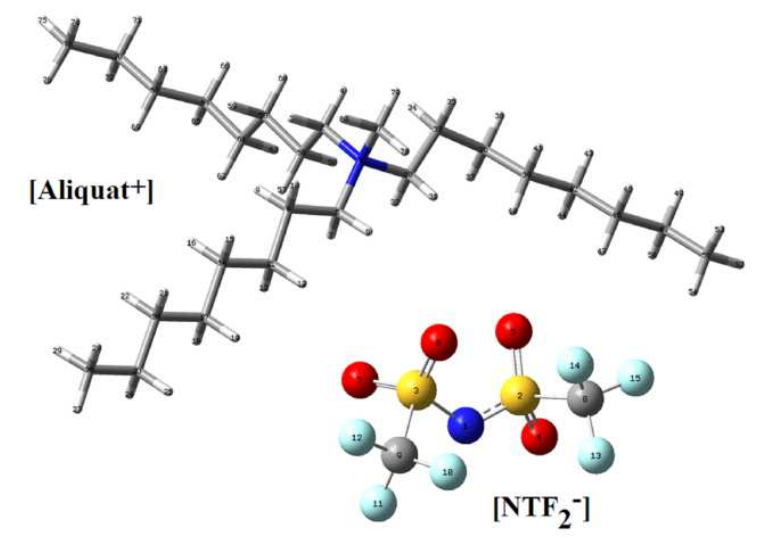

Figure 1. Structures of [Aliquat $\left.{ }^{+}\right]$cation and $\left[\mathrm{NTf}_{2}^{-}\right]$ anion species of $\left[\right.$ Aliquat $\left.^{+}\right]\left[\mathrm{NTf}_{2}^{-}\right]$ionic liquid and atoms labelling.

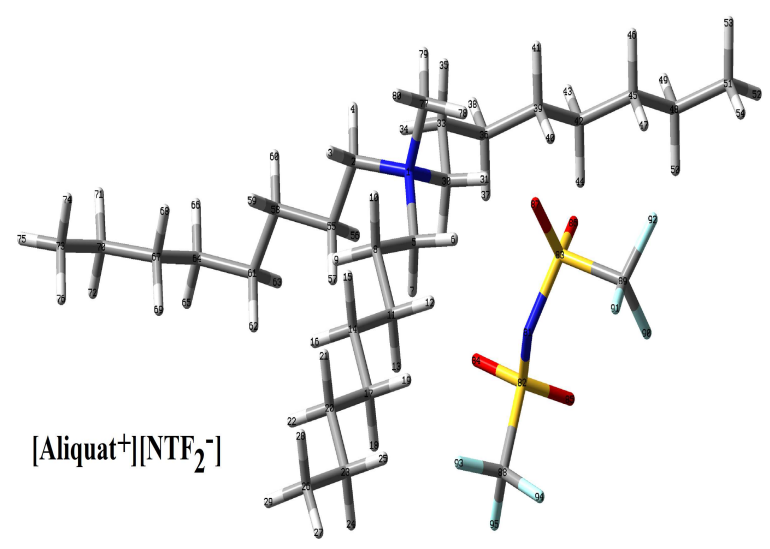

Figure 2. Structure of $\left[\right.$ Aliquat $\left.^{+}\right]\left[\mathrm{NTf}_{2}^{-}\right]$ionic liquid and atoms labelling.

Natural bond orbital (NBO) and atoms in molecules (AIM) calculations were performed in order to investigate donor-acceptor energy interactions, atomic charges, molecular electrostatic potentials, bond orders, and topological properties of those three species at the same level of theory [55-58]. Then, the determinations of force fields of cation and anion 
were carried out with the scaled quantum mechanical force field (SQMFF) methodology by using the normal internal coordinates, transferable scaling factors and the Version 7.0 of Molvib program [59-61] while the vibrational assignments for the ionic liquid were performed with the aid of GaussView program and, using a scale factor only for the vibration modes corresponding to higher wavenumbers [51]. Known equations were used to transform the Raman spectra predicted in activities for the three species to intensities $[62,63]$. On the other side, the gauge-including atomic orbital (GIAO) method was used to predict the ${ }^{1} \mathrm{H}$ and ${ }^{13} \mathrm{C}-\mathrm{NMR}$ chemical shifts because it is a quantum mechanical technique for the calculation of magnetic properties of chemical systems [64]. Finally, the gap values together with interesting chemical potential $(\mu)$, electronegativity $(\chi)$, global hardness $(\eta)$, global softness $(S)$, global electrophilicity index $(\omega)$ and global nucleophilicity index $(E)$ descriptors were calculated from their corresponding frontier orbitals $[34,37,38]$.

\section{Results and discussion}

\subsection{NMR results}

In order to confirm the absence of significant impurities in the investigated IL, the ${ }^{1} \mathrm{H},{ }^{13} \mathrm{C}$ and ${ }^{19} \mathrm{~F}-\mathrm{NMR}$ spectroscopy was used to confirm the formation of the [Aliquat $\left.{ }^{+}\right]\left[\mathrm{NTf}_{2}{ }^{-}\right.$] IL by anionic exchange from $\left[\right.$ Aliquat $\left.^{+}\right]\left[\mathrm{Cl}^{-}\right]$. The spectroscopic data are given below and the $\mathrm{H}$ and $\mathrm{C}$ atom labelling and the corresponding spectra are shown in Figure 3 (A, B and C).

[Aliquat $\left.{ }^{+}\right]\left[\mathbf{N T f}_{2}{ }^{-}\right]:{ }^{1} \mathbf{H}-\mathbf{N M R}\left(400 \mathrm{MHz},\left(\mathrm{CDCl}_{3}\right) \delta_{\mathrm{H}}(\mathrm{ppm})=3.11-3.15\left(\mathrm{~N}^{+}-\left(\mathrm{CH}_{2}\right)_{\mathrm{n}}-, 6 \mathrm{H}\right), 2.96\right.$ $\left(\mathrm{N}^{+}-\mathrm{CH}_{3}, 3 \mathrm{H}\right), 1.58\left(\mathrm{~N}^{+}-\left(\mathrm{CH}_{2}\right)-\left(\mathrm{CH}_{2}\right)-, 6 \mathrm{H}\right), 1.23-1.31\left(-\left(\mathrm{CH}_{2}\right)_{\mathrm{n}}-, 30 \mathrm{H}\right), 0.83-086\left(-\left(\mathrm{CH}_{2}\right)_{\mathrm{n}}-\right.$ $\left.\mathrm{CH}_{3}, J=4 \mathrm{~Hz}, 9 \mathrm{H}\right) .{ }^{13} \mathbf{C}-\mathbf{N M R}\left(100 \mathrm{MHz},\left(\mathrm{CDCl}_{3}\right) \delta_{\mathrm{C}}(\mathrm{ppm})=121.07\left(\mathrm{C}_{\text {anion }}\right), 118.14\left(\mathrm{C}_{\text {anion }}\right)\right.$, 61.62 (C7), 48.34 (C8), 31.60, 31.42 (C6), 28.79 (C5), 25.95 (C4), 22.49 (C3), 22.39 (C2), $13.86(\mathrm{C} 1) .{ }^{19} \mathbf{F}-\mathbf{N M R}\left(100 \mathrm{MHz}, \mathrm{CDCl}_{3}\right) \delta_{\mathrm{F}}(\mathrm{ppm})=-78.82 \mathrm{ppm}$ singulet.

As shown in Figure 3 (A), the signals at $\delta=3.11-3.15 \mathrm{ppm}$ were assigned to the methylene protons on the alkyl rings $\mathrm{N}^{+}-\left(\mathrm{CH}_{2}\right)_{\mathrm{n}}-$. The signal at $\delta=2.96 \mathrm{ppm}$ corresponding to the $\mathrm{N}^{+}-$ $\mathrm{CH}_{3}$, thus, another three signals in the range of $\delta=1.58$, broad at $\delta=1.23-1.31 \mathrm{ppm}$ and $\delta$ $=0.83-086$ ppm were attributed to the methylene $\mathrm{N}^{+}-\left(\mathrm{CH}_{2}\right)-\left(\mathrm{CH}_{2}\right)-$ and $-\left(\mathrm{CH}_{2}\right)_{\mathrm{n}}-$ groups in octyl chains and terminal methyl group $-\left(\mathrm{CH}_{2}\right)_{\mathrm{n}}-\mathrm{CH}_{3}$ respectively. 

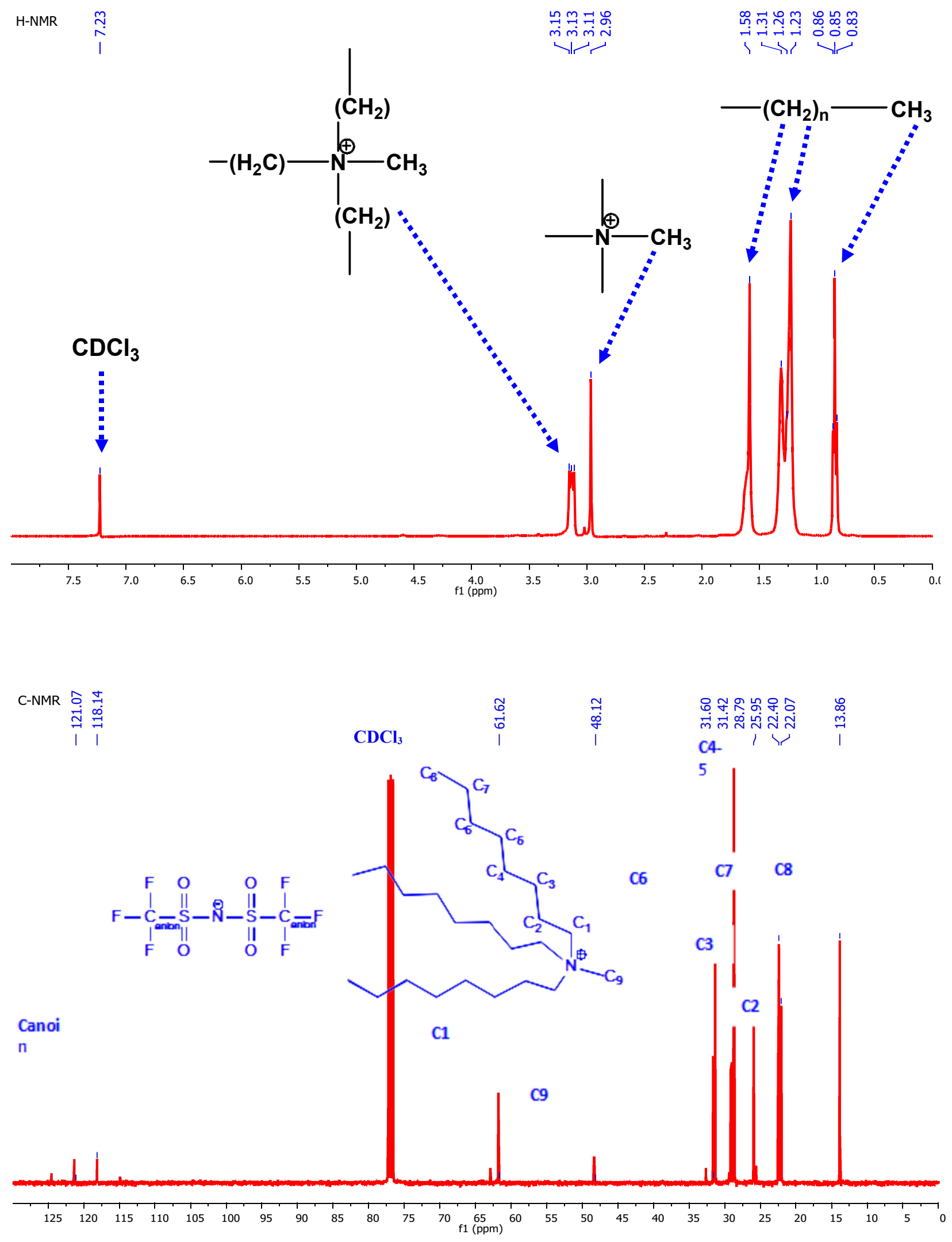

8 


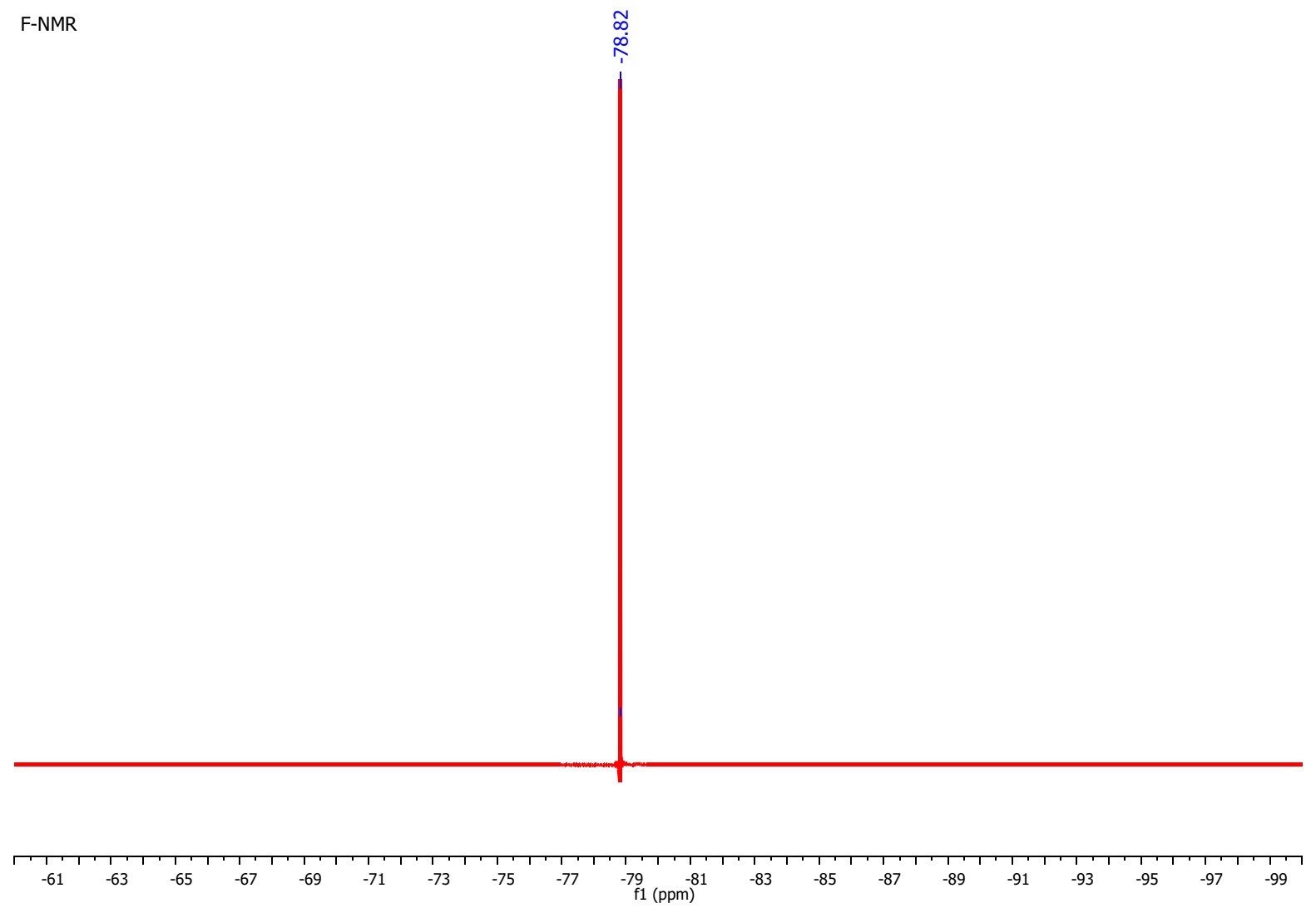

Figure 3. Hydrogen atom labeling and ${ }^{1} \mathrm{H}-\mathrm{NMR}$ spectrum, carbon atom labeling and ${ }^{13} \mathrm{C}$ NMR spectrum and ${ }^{19}$ F-NMR spectrum of ([Aliquat $\left.\left.{ }^{+}\right]\left[\mathrm{NTf}_{2}{ }^{-}\right]\right)$.

Moreover, the anionic exchange replacement of the chloride by bis(trifluoromethylsulfonyl)imide is demonstrated by the appearance of two new signals in the $13 \mathrm{C}$ spectrum (Figure 3 B) as a doublet at $\delta=121.07 / 118.14 \mathrm{ppm}$ corresponding to the signature of the carbon of the $\left[\mathrm{NTf}_{2}^{-}\right]$anion indicating the successful synthesis of [Aliquat ${ }^{+}$] [NTf ${ }_{2}^{-}$. Comparisons of predicted ${ }^{1} \mathrm{H}$ and ${ }^{13} \mathrm{C}-\mathrm{NMR}$ chemical shifts by using the GIAO/B3LYP/6-31G* method for the $\left[\right.$ Aliquat $\left.^{+}\right]\left[\mathrm{NTf}_{2}{ }^{-}\right]$IL in gas phase by using the rootmean-square deviation (RMSD) values show a better correlation for the $\mathrm{H}$ nuclei $(0.5 \mathrm{ppm})$ than the $\mathrm{C}$ atoms (20.3 ppm) [64]. The employed method and the gas medium justify such differences. Here, the IL calculations were not optimized in a solution.

\subsection{Optimization geometries}

The hybrid B3LYP/6-31G* method was used to optimize the ionic liquid couple due to the 95 atoms present in the structure; for comparison its cationic and anionic species were also optimized at the same level of theory. When the anion is optimized with $C_{2 V}$ symmetry by using the B3LYP/6-31G* method imaginary frequencies are obtained, while if this species is 
optimized with $C_{1}$ symmetry all positive frequencies are calculated when the $6-311++\mathrm{G}^{* *}$ basis set is used. On the contrary, both cation and ionic liquid species are optimized with $C_{1}$ symmetry and all positive frequencies are obtained by using the B3LYP/6-31G* basis set. Calculated total energies, dipole moments and volumes of cation, anion and [Aliquat $\left.{ }^{+}\right]\left[\mathrm{NTf}_{2}^{-}\right]$ ionic liquid in gas phase by using the functional hybrid B3LYP method and the 6-31G* and 6-311++G** basis sets can be seen in Table 1. Comparing the properties for the anion with both methods it is observed that lower dipole moment and volume values are obtained with the higher size basis set.

Table 1. Calculated total energies $(E)$, dipole moments $(\mu)$ and volumes $(V)$ for cation, anion and $\left[\right.$ Aliquat $\left.{ }^{+}\right]\left[\mathrm{NTf}_{2}^{-}\right]$ionic liquid in gas phase by using the hybrid B3LYP/6-31G* Method.

\begin{tabular}{|c|c|c|c|}
\hline \multicolumn{4}{|c|}{ B3LYP/6-31G* Method } \\
\hline Species & E (Hartrees) & $\mu(\mathrm{D})$ & $\mathrm{V}\left(\AA^{3}\right)$ \\
\hline$\left[\mathrm{NTf}_{2}^{-}\right]^{\#}\left(C_{2 v}\right)$ & -1827.0348 & 5.49 & 185.5 \\
\hline [Aliquat $^{+}$] $\left(C_{l}\right)$ & -1039.7644 & 4.67 & 509.0 \\
\hline$\left[\right.$ Aliquat $\left.^{+}\right]\left[\mathrm{NTf}_{2}{ }^{-}\right]\left(C_{l}\right)$ & -2867.0854 & 13.62 & 690.4 \\
\hline \multicolumn{4}{|c|}{ B3LYP/6-311++G** Method } \\
\hline$\left[\mathrm{NTf}_{2}^{-}\right]\left(C_{1}\right)$ & -1827.6092 & 4.36 & 183.3 \\
\hline
\end{tabular}

As expected due to its larger size, the $\left[\right.$ Aliquat $\left.^{+}\right]\left[\mathrm{NTf}_{2}^{-}\right]$ionic couple presents higher dipole moment and volume. Regarding the dipole moment vectors for the three species in gas phase by using the two B3LYP/6-31G* and B3LYP/6-311++G** levels of theory, it is observed from Figure S1 that orientations and directions of dipole moment vectors for the anionic and cationic species change notably in the ionic couple. Thus, in the anion the vector is located from centre of $\mathrm{N}$ atom in direction towards outside of two $\mathrm{CF}_{3}$ groups while in the cationic species; the vector is located forming a certain angle in the direction of $\mathrm{N} 1-\mathrm{CH}_{3}$ bond, as shown in Fig. S1. On the other hand, in the ionic liquid, the vector is practically parallel to $\mathrm{N} 1-\mathrm{CH}_{3}$ bond in direction towards the large side chain. These results show that in the formation of ionic liquid the anion and the cation modify their dipole moment vector s.

Also other parameters are modified passing from the isolated ions to the ionic couple.In Table 2 the calculated bond lengths and angles for anion, cation and ionic couple in the gas phase are summarized by using two levels of theory. The differences between cation and IL and between anion and IL are expressed by means of the root-mean-square deviation (RMSD) values.

Table 2. Comparison of calculated geometrical parameters for cation, anion and $\left[\mathrm{Aliquat}^{+}\right]\left[\mathrm{NTf}_{2}{ }^{-}\right]$ionic liquid in gas phase at different levels of theory. 


\begin{tabular}{|c|c|c|c|c|c|}
\hline \multicolumn{6}{|c|}{ B3LYP/6-31G*a } \\
\hline Bond lengths $(\AA)$ & [Aliquat $^{+}$] & {$\left[\right.$Aliquat $\left.^{+}\right]\left[\mathrm{NTf}_{2}^{-}\right]$} & Bond angles $\left({ }^{\circ}\right)$ & [Aliquat $^{+}$] & {$\left[\right.$Aliquat $\left.^{+}\right]\left[\mathrm{NTf}_{2}^{-}\right]$} \\
\hline N1-C2 (R) & 1.531 & 1.517 & C2-N1-C5 & 111.6 & 111.5 \\
\hline N1-C5 (R) & 1.536 & 1.539 & C2-N1-C30 & 112.0 & 112.0 \\
\hline N1-C30 (R) & 1.536 & 1.541 & $\mathrm{C} 5-\mathrm{N} 1-\mathrm{C} 30$ & 106.4 & 107.2 \\
\hline $\mathrm{N} 1-\mathrm{C} 77\left(\mathrm{CH}_{3}\right)$ & 1.505 & 1.505 & C2-N1-C77 & 107.9 & 108.8 \\
\hline RMSD & & 0.008 & & & 1.1 \\
\hline Bond lengths $(\AA)$ & {$\left[\mathrm{NTf}_{2}^{-}\right]^{\#}$} & {$\left[\right.$ Aliquat $\left.^{+}\right]\left[\mathrm{NTf}_{2}^{-}\right]$} & Bond angles $\left({ }^{\circ}\right)$ & {$\left[\mathrm{NTf}_{2}^{-}\right]^{\#}$} & {$\left[\right.$ Aliquat $\left.^{+}\right]\left[\mathrm{NTf}_{2}^{-}\right]$} \\
\hline N81-S82 & 1.599 & 1.631 & S82-N81-S83 & 125.9 & 122.3 \\
\hline N81-S83 & 1.614 & 1.605 & O84-S82-O85 & 119.3 & 118.2 \\
\hline S82-O84 & 1.460 & 1.479 & O86-S83-O87 & 118.2 & 117.3 \\
\hline S82-O85 & 1.463 & 1.464 & N81-S82-O84 & 108.7 & 111.6 \\
\hline S83-O86 & 1.463 & 1.474 & N81-S83-O87 & 113.1 & 108.1 \\
\hline S83-O87 & 1.462 & 1.477 & N81-S82-C88 & 96.0 & 96.6 \\
\hline S82-C88 & 1.897 & 1.868 & N81-S83-C89 & 103.9 & 104.6 \\
\hline S83-C89 & 1.891 & 1.869 & & & \\
\hline RMSD & & 0.020 & & & 2.7 \\
\hline
\end{tabular}

${ }^{\text {a }}$ This work, "From B3LYP/6-311++G** method; RMSD values in letter bold.

The higher differences in the RMSD values are observed in bond lengths and angles of the anion with values of $0.020 \AA$ for lengths and $2.7^{\circ}$ for angles while for the cation the variations for bond lengths and angles are $\sim 0.008 \AA$ and $1.1^{\circ}$, respectively. This way, the anion undergoes important changes in the formation of IL. These observations could be justified due to the long side chains that probably stabilize anion and cation in the IL.

\subsection{Atomic charges, molecular electrostatic potentials and bond orders}

The slight modifications observed in the geometrical parameters of anion suggest that this species play a important role in the formation of IL and in their properties and, for this reason, atomic charges, molecular electrostatic potentials and bond orders are investigated for cation and anion by separate and, then, for the IL. Hence, in Table S1 we presented atomic MerzKollman (MK), Mulliken and natural population (NPA) charges, molecular electrostatic potentials and bond orders only for the atoms corresponding to cation and anion of those three species in gas phase. Note that for the cation only the three types of charges on N1 atoms are compared in Table S1 with that corresponding to IL while in Figure S2 we presented the variations in MK, Mulliken and NPA charges observed only on the atoms corresponding to anion and to IL. Analyzing the three charges on the N1 atoms of cation it is observed that only the MK charge on N1 of cation (0.133 a.u.) is different from that observed in the IL (-0.376 a.u.) while the Mulliken and NPA charges are practically the same in both species. Hence, the 
values of the MK charges on N1 atoms demonstrate differences between the cationic and IL species. Then, the graphics shows important differences among those charges. Hence, Figure $\mathrm{S} 2$ (a) shows differences in the Mulliken charges on the $\mathrm{S}, \mathrm{O}, \mathrm{C}$ and $\mathrm{F}$ atoms belonging to anion and IL observing higher positive values on the S2, S3, C8 and C9 atoms and more negative values on the four $\mathrm{O}$ atoms of IL. Besides, the two $\mathrm{S}$ and $\mathrm{C}$ atoms present the same charges values in the IL but different in the anionic species while the Mulliken charges on the $\mathrm{N} 1$ atoms remains practically constant in the anion and IL and, only more negative charges values are observed on the six F atoms of IL. On the other side, Figure S2 (b) reveals differences in the MK charges on S2 and S3 atoms showing higher values for S3 in the anion and S2 in the IL. The charges on C8 atoms in both species are the same while the MK charge on C9 is higher in the IL. The MK charges on the four $\mathrm{O}$ atoms are more negative in the anion while the charges on O5 and O6 are less negative in the IL. The MK charges on the six F atoms are slightly higher in the anion than the observed in IL. On the contrary, Figure S2 (c) evidence practically the same NPA charges on all atoms of both species. Hence, the NPA charges have practically no influence on the properties of IL. These studies show that the different MK charges on two $\mathrm{S}$ and $\mathrm{C}$ atoms evidence different behaviours of $\left[\mathrm{NTf}_{2}^{-}\right]$groups in the anion of IL and, hence, suggest different coordination modes of these groups in the IL while the same Mulliken charges values on those atoms suggest similar coordination modes of those groups in the IL.

When the molecular electrostatic potentials (MEPs) on N1 atom of the cation (-18.080 a.u.) is compared with the corresponding to IL (-18.196 a.u.) (see Table S1) a more negative value is observed in the IL. However, when the MEPs on the atoms of anion and IL are compared the values remain unchanged, as observed in Figure S3. This result is similar to what was observed forthe MK charge on N1 atom of cation, as expected because the MEP values are obtained from those MK charges [55]. Therefore, both MK charges and MEP values indicate that the incorporation of anion has influence on the cation in the formation of [Aliquat ${ }^{+}$] $\left[\mathrm{NTf}_{2}^{-}\right]$ionic liquid. If now the mapped MEP surfaces for the three species are compared in order to investigate the nucleophilic and electrophilic regions one can observe in Figure S4 that the mapped surface of cation is completely blue being stronger the coloration around the quaternary $\mathrm{N}$, as expected because this species is positively charged. Hence, the cation is electrophilic while the mapped surface of anion is totally red due to that this species is negatively charged. Strong red colours are observed on the $\mathrm{SO}_{2}$ groups of anion. Hence, the 
anion is nucleophilic. On the contrary, the mapped surface of the IL shows less strong red and blue colorations on the $\mathrm{SO}_{2}$ groups of anion and on the quaternary $\mathrm{N}$ of cation, respectively.

Another interesting property to investigate in the cation, anion and IL is the bond order (BO) expressed as Wiberg index. Thus, from Table S1 when the value for N1 atom of cation is compared with the corresponding value of IL we observed the same values (3.594); however, when the BOs of the atoms of anion are compared with the corresponding to IL the values slightly change for the $\mathrm{S}$ and $\mathrm{O}$ atoms while for the remain atoms the values are practically similar, as observed in Figure S5. These results show that possibly those S and O atoms belonging to $\left[\mathrm{NTf}_{2}^{-}\right]$anion will be involved in the coordination modes to cation during the formation of IL and, for these reasons, the BOs values of those atoms change.

\subsection{NBO and AIM studies}

The presence of intra-molecular or $\mathrm{H}$ bonds interactions stabilize an ionic liquid, as observed in previous related studies [34,37,38] and, for these reasons, the second order perturbation theory analyses of Fock matrix in NBO Basis and the topological properties were calculated for the IL and its cationic and anionic species in gas phase by using the NBO and AIM 2000 programs, respectively [56-58]. Both calculations are important and useful to determine different transitions and ionic or $\mathrm{H}$ bond interactions. The interactions observed by NBO calculations for the cation present very low energies $(<<<10 \mathrm{kcal} / \mathrm{mol})$ and, for these reasons, they are no presented here. Therefore, calculated donor-acceptor energy interactions for anion and IL in gas phase at different levels of theory are observed in Table S2. Only, two types of interactions are observed in both species which are the $n \rightarrow \sigma^{*}$ and $\sigma^{*} \rightarrow \sigma^{*}$ interactions. In the former interactions transitions from lone pairs of $\mathrm{N}, \mathrm{O}$ and $\mathrm{F}$ atoms corresponding to anion and IL to anti-bonding N-S, S-O, S-C and C-F orbitals are involved, as detailed in Table S2. Note that the energies of these interactions are higher in the IL $(1856.42 \mathrm{~kJ} / \mathrm{mol})$, as compared with the observed for the anion $(203.36 \mathrm{~kJ} / \mathrm{mol})$, while in the $\sigma^{*} \rightarrow \sigma^{*}$ interactions transitions from anti-bonding N-S and S-O orbitals to anti-bonding N-S and S-O orbitals are involved. These interactions are also higher in the IL than in the corresponding anion. Hence, the total energy clearly favours the IL $(2317.22 \mathrm{~kJ} / \mathrm{mol})$ and reveals that cation increases in significant form the energy of the anion $(366.84 \mathrm{~kJ} / \mathrm{mol})$ due to the additional transitions.

The topological properties allows to determine the nature of different interactions such as, intra-molecular, $\mathrm{H}$ bonds, ionic, covalent polar, etc., by using the AIM 2000 program and the Bader's theory of atoms in molecules [57,58]. The electron density, $\rho(r)$, the Laplacian 
values, $\nabla^{2} \rho(r)$, the eigenvalues $(\lambda 1, \lambda 2, \lambda 3)$ of the Hessian matrix and, the $|\lambda 1| / \lambda 3$ ratio should be calculated in the bond critical points (BCPs) and ring critical points (RCPs). Thus, these calculations were performed for the cation, anion and IL in gas phase at different levels of theory. In the cationic species in gas phase no new interactions are observed, while for the anion and the IL in gas phase the topological properties are modified as reported in Table S3. In the anion, only an $\mathrm{H}$ bond interaction with characteristics corresponding to an ionic or highly polar covalent interaction can be seen where $\lambda 1 / \lambda 3<1$ and $\nabla^{2} \rho(r)>0$ (closed-shell interaction). The new S3-O6 $\cdots$ F14 interaction formed in the anion is shown in the molecular graphic presented in Figure S6 which form a RCP named RCPN. In the IL eleven new interactions are observed where only nine of them have characteristics of $\mathrm{H}$ bonds interactions and six of them are of type S-O $\cdots \mathrm{H}$, two of type $\mathrm{C}-\mathrm{H} \cdots \mathrm{H}$ and one $\mathrm{C}-\mathrm{H} \cdots \mathrm{N}$, another is ionic,

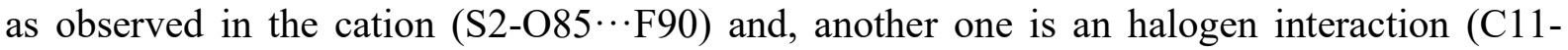
H13 $\cdots$ F93). Due to number of interactions and to the complexity of molecular graphic for the IL only some interactions can be observed in Figure S7 but, all topological properties for those eleven interactions are presented in Table S3. Note that the closer distances between the involved atoms are observed in the two $\mathrm{C}-\mathrm{H} \cdots \mathrm{H}$ interactions $(2.159 / 2.151 \AA$ ) while the ionic interaction presents higher distance between the $\mathrm{O}$ and $\mathrm{F}$ atoms $(3.170 \AA)$. In the IL, three $\mathrm{O}$ atoms (O84, $\mathrm{O} 86$ and $\mathrm{O} 87)$ of anionic species are coordinated to two $\mathrm{H}$ atoms by $\mathrm{S}-\mathrm{O} \cdots \mathrm{H}$ interactions, as graphed in Figure S8 by using the Moldraw program [65]. Hence, hexadentate coordination mode can be seen in the IL and, due to number of interactions present, this species is the more stable than the anionic one, as expected because the ionic charged species are unstable.

\subsection{Frontier orbitals studies}

Comparisons of calculated geometrical parameters for cation, anion and IL have shown that anion undergoes changes in the formation of IL, while the different MK charges observed on $\mathrm{N} 1$ atoms of cation and IL suggest that this property is modified in the IL. On the other hand, the interactions predicted in the IL by using NBO and AIM calculations reveal different characteristics and support a hexadentate coordination mode between cation and anion of IL. Hence, the high number of interactions and high dipole moment and volume values of IL justify its higher stability as compared to the cationic and anionic species. Now, in order to investigate the reactivities and behaviours of those three species in gas phase, the highest occupied molecular orbital (HOMO) and lowest unoccupied molecular orbital (LUMO) were calculated together with the energies of gap values and the chemical potential $(\mu)$, 
electronegativity $(\chi)$, global hardness $(\eta)$, global softness $(S)$, global electrophilicity index $(\omega)$ and global nucleophilicity index $(E)$ descriptors [34,37,38]. These results and the equations used to calculate the descriptors are presented in Table S4. The values for the three species are compared in Table S5 with those reported for other ionic liquids such as, 1-ethyl-3methylimidazolium hexafluorophosphate [34], 1-buthyl-3-methyl imidazolium nitrate [37] and 1-buthyl-3-methyl imidazolium trifluoromethanesulfonate [38]. Comparing first the gap values for cation and anion of [Aliquat $\left.{ }^{+}\right]\left[\mathrm{NTf}_{2}{ }^{-}\right]$IL it is observed that cation gap $(8.2152 \mathrm{eV})$ is higher than anion gap $(7.2600 \mathrm{eV})$ and, that the anion produces a decrease in the gap value of IL $(7.5158 \mathrm{eV})$. Therefore, the most reactive species with low gap value is the anion, in agreement with the low stabilization energy calculated by NBO analysis, while the less reactive species is the cation probably due to the three large side chains. The IL is more stable than the anion due to the eleven interactions observed by AIM analysis and to high number of transitions evidenced by NBO studies. If now the gap values for cation and anion of $\left[\right.$ Aliquat $\left.^{+}\right]\left[\mathrm{NTf}_{2}{ }^{-}\right]$IL are compared with $\left[\mathrm{EMIM}^{+}\right]\left[\mathrm{PF}_{6}^{-}\right]$IL and its $\left[\mathrm{EMIM}^{+}\right]$cation and $\left[\mathrm{PF}_{6}^{-}\right]$ anion [34], it is observed higher reactivities in $\left[\mathrm{EMIM}^{+}\right]\left[\mathrm{PF}_{6}^{-}\right] \mathrm{IL}$ and its cation but the $\left[\mathrm{PF}_{6}^{-}\right]$ anion is less reactive than $\left[\mathrm{NTf}_{2}^{-}\right]$. On the other side, both [BMIM][OTF] and [BMIM] $\left[\mathrm{NO}_{3}\right]$ ILs are more reactive than the other ones being, 1-buthyl-3-methyl imidazolium nitrate the most reactive. Regarding the global electrophilicity index $(\omega)$ and global nucleophilicity index $(E)$ the cation of [Aliquat $\left.{ }^{+}\right]\left[\mathrm{NTf}_{2}{ }^{-}\right]$IL presents the higher values $(\omega=4.7950 \mathrm{eV}$ and $E=$ $-25.7805 \mathrm{eV}$ ), as compared with the anion and IL while the $\left[\mathrm{EMIM}^{+}\right]$cation shows higher values $(\omega=10.9934 \mathrm{eV}$ and $E=-28.6227 \mathrm{eV})$ than the other one.

\subsection{Thermal analysis}

The knowledge of the thermal properties of ILs is crucial from an engineering point of view as they are important parameters for determining process conditions. In order to obtain a comprehensive picture of the thermal behaviour, two complementary thermal analysis techniques were used. Firstly, knowing that $\left[\left(\left[\right.\right.\right.$ Aliquat $\left.\left.^{+}\right]\left[\mathrm{NTf}_{2}^{-}\right]\right)$is liquids at room temperature, upon heating, we observed that the thermal decomposition occurs in the temperature range $\approx 360-500{ }^{\circ} \mathrm{C}$, with a mass loss that reaches $83 \%$ at $483{ }^{\circ} \mathrm{C}$. 

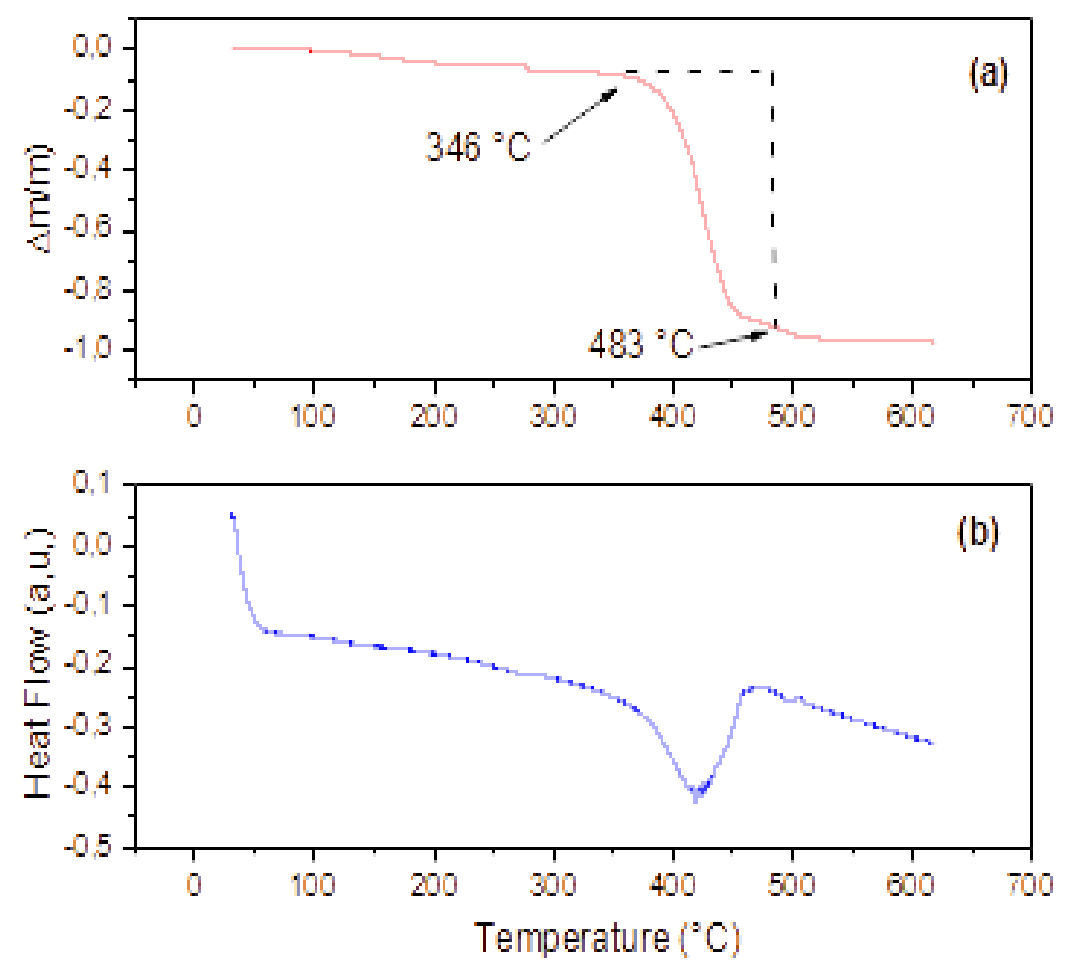

Figure 4. TGA (a) and DTA (b) curves of ([Aliquat $\left.\left.{ }^{+}\right]\left[\mathrm{NTf}_{2}^{-}\right]\right)$ILs.

Comparing our TGA measurements of ([Aliquat $\left.\left.{ }^{+}\right]\left[\mathrm{NTf}_{2}^{-}\right]\right)$with those reported by Mikkola et al [27], it can be noted that $\left[\left(\left[\right.\right.\right.$ Aliquat $\left.\left.^{+}\right]\left[\mathrm{NTf}_{2}^{-}\right]\right)$is thermally more stable than [Aliquat $\left.{ }^{+}\right]$ containing the nitrate $\left[\mathrm{NO}_{3}^{-}\right]\left(\mathrm{T}_{\mathrm{d}}=202{ }^{\circ} \mathrm{C}\right)$, hexafluorophosphate $\left[\mathrm{PF}_{6}^{-}\right]\left(\mathrm{T}_{\mathrm{d}}=274{ }^{\circ} \mathrm{C}\right)$ and tetrafluoroborate $\left[\mathrm{BF}_{4}^{-}\right]$anion $\left(\mathrm{T}_{\mathrm{d}}=294^{\circ} \mathrm{C}\right)$. Many previous studies indicated that the thermal stability of ionic liquids strongly depends on the type of anion [67], the fact that ([Aliquat $\left.{ }^{+}\right]$ $\left[\mathrm{NTf}_{2}^{-}\right]$) is thermally more stable than the cited ILs [27] can be explained by the high thermal stability of bis(trifluoromethylsulfonyl)imide anion, its larger size and molecular structure $[31,66]$. As reported in Figure 4, the DTA curves confirm that the decomposition temperature for $\left(\left[\right.\right.$ Aliquat $\left.\left.^{+}\right]\left[\mathrm{NTf}_{2}^{-}\right]\right)$was found at $483{ }^{\circ} \mathrm{C}$.

\subsection{Vibrational studies}

B3LYP/6-31G* calculations have optimized the cation and IL with $C_{l}$ symmetries while the anion was optimized with the same symmetry but by using the B3LYP/6-311++G** method. Due to the presence of 80 and 15 atoms in the structures of cation and anion, respectively, 234 and 39 vibration modes are expected in these species while in the IL a total of 279 vibration are expected. The vibration modes of the three species present activity in both infrared and Raman spectra. Here, the scaled quantum mechanical force field (SQMFF) methodology was 
used to determine the force fields of cation and anion considering the corresponding normal internal coordinates, transferable scaling factors and the Molvib program [59-61] while the vibrational assignments for the ionic liquid were performed with the aid of GaussView program and, using a scale factor only for the vibration modes corresponding to the higher wavenumbers region [51]. In the definition of normal internal coordinates of cation the quaternary $\mathrm{N}$ atoms was considered with $\mathrm{C}_{3 \mathrm{v}}$ symmetry because that atoms is linked to three similar side chains and to a $\mathrm{CH}_{3}$ groups. Vibrational measurements are carried out using FTIR-ATR and RAMAN techniques. In Figures 5 and $\mathbf{6}$ we presented respectively the experimental ATR and Raman spectra of [Aliquat $\left.{ }^{+}\right]\left[\mathrm{NTf}_{2}^{-}\right]$IL in solid phase compared with the predicted for the cation, anion species and IL in gas phase by using the hybrid B3LYP method. A detailed investigation of the vibrational frequencies and the assignment of the observed bands are provided in Table 3 and will be discussed in the following sub-sections.

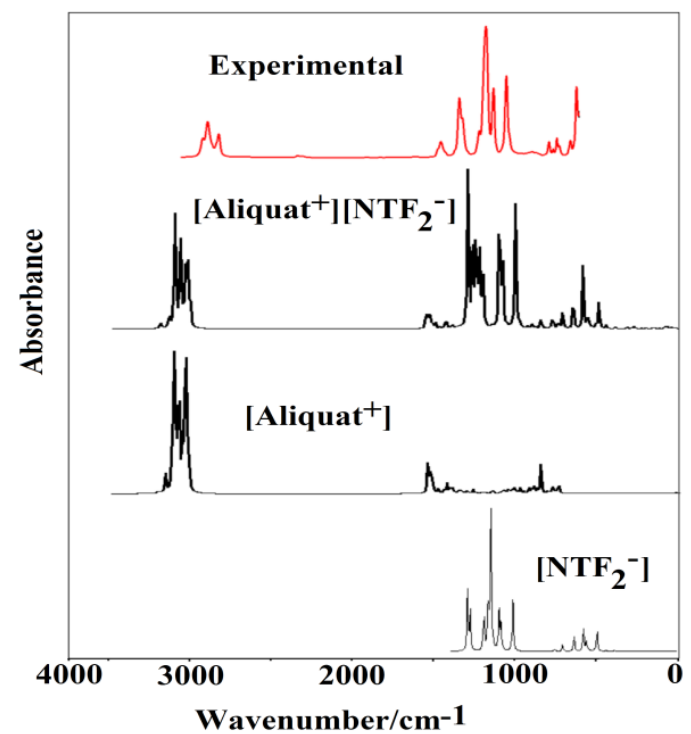

Figure 5. Experimental Infrared spectra of [Aliquat $\left.{ }^{+}\right]\left[\mathrm{NTf}_{2}^{-}\right] \quad$ IL in liquid phase compared with the predicted for the cation, anion and IL in gas phase by using the hybrid B3LYP method.

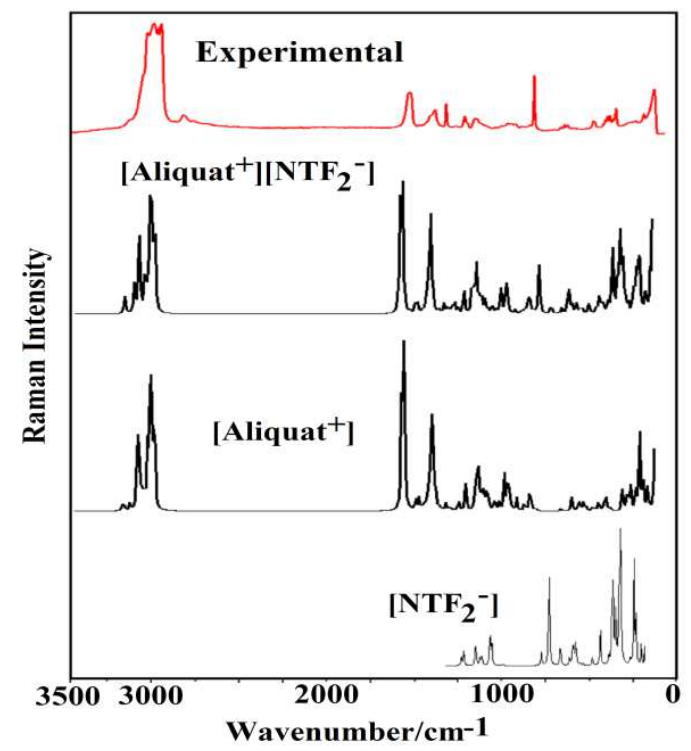

Figure 6. Experimental Raman spectra of [Aliquat $\left.{ }^{+}\right]\left[\mathrm{NTf}_{2}{ }^{-}\right] \mathrm{IL}$ in liquid phase compared with the predicted for the cation, anion and IL in gas phase by using the hybrid B3LYP method.

Table 3. Observed and calculated wavenumbers $\left(\mathrm{cm}^{-1}\right)$ and assignments for [Aliquat $\left.{ }^{+}\right]\left[\mathrm{NTf}_{2}^{-}\right]$ionic liquid and its cation and anion in gas phase by using the hybrid B3LYP method and different basis sets.

\begin{tabular}{|c|c|c|c|c|c|}
\hline & $\operatorname{Exp}^{\mathrm{a}}$ & \multicolumn{4}{|c|}{ B3LYP method ${ }^{a}$} \\
\hline \multirow{3}{*}{ IR } & \multirow{3}{*}{ Raman } & $6-311++\mathrm{G}^{* *}$ & \multicolumn{3}{|c|}{$6-31 \mathrm{G}^{*}$} \\
\hline & & {$\left[\mathrm{NTf}_{2}^{-}\right]$} & [Aliquat $^{+}$] & & $\left.\mathrm{at}^{+}\right]\left[\mathrm{NTf}_{2}^{-}\right]$ \\
\hline & & Assignments $^{a}$ & Assignments $^{\mathrm{a}}$ & SQM $^{\mathrm{d}}$ & Assignments \\
\hline
\end{tabular}




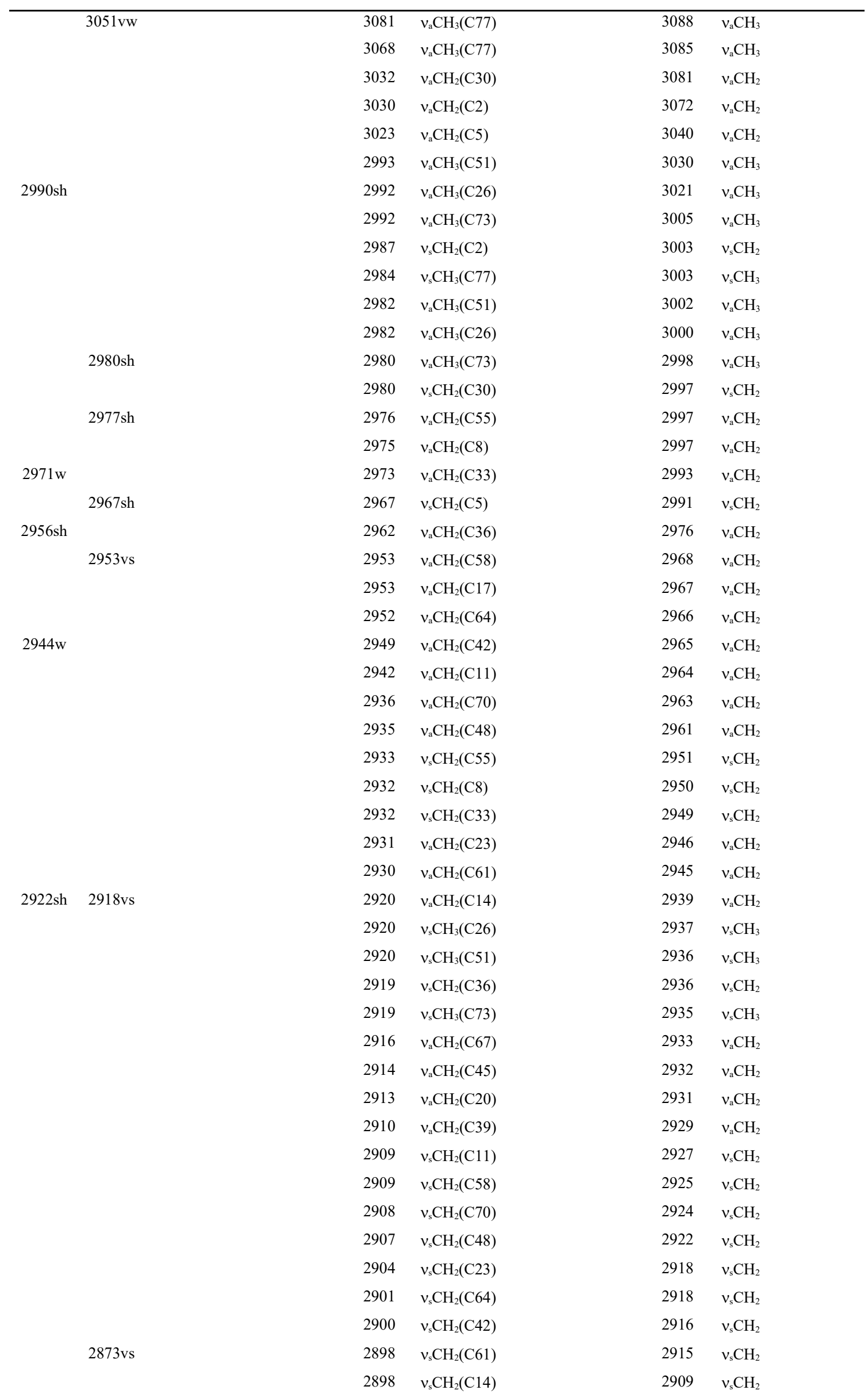




\begin{tabular}{|c|c|c|c|c|c|}
\hline & & 2893 & $v_{\mathrm{s}} \mathrm{CH}_{2}(\mathrm{C} 17)$ & 2909 & $v_{\mathrm{s}} \mathrm{CH}_{2}$ \\
\hline \multirow[t]{3}{*}{ 2890sh } & & 2890 & $v_{\mathrm{s}} \mathrm{CH}_{2}(\mathrm{C} 67)$ & 2907 & $v_{\mathrm{s}} \mathrm{CH}_{2}$ \\
\hline & & 2890 & $v_{\mathrm{s}} \mathrm{CH}_{2}(\mathrm{C} 45)$ & 2907 & $v_{\mathrm{s}} \mathrm{CH}_{2}$ \\
\hline & & 2890 & $v_{\mathrm{s}} \mathrm{CH}_{2}(\mathrm{C} 20)$ & 2906 & $v_{\mathrm{s}} \mathrm{CH}_{2}$ \\
\hline \multirow[t]{2}{*}{$2874 w$} & $2747 w$ & 2886 & $v_{\mathrm{s}} \mathrm{CH}_{2}(\mathrm{C} 39)$ & 2903 & $v_{\mathrm{s}} \mathrm{CH}_{2}$ \\
\hline & & 1496 & $\delta \mathrm{CH}_{2}(\mathrm{C} 42) \delta \mathrm{C} 39 \mathrm{C} 42 \mathrm{C} 45$ & 1558 & $\delta \mathrm{CH} 2, \delta \mathrm{C} 39 \mathrm{C} 42 \mathrm{C} 45$ \\
\hline \multirow[t]{5}{*}{$1491 \mathrm{sh}$} & $1487 \mathrm{sh}$ & 1486 & $\delta_{\mathrm{a}} \mathrm{CH}_{3}(\mathrm{C} 77)$ & 1546 & $\delta_{\mathrm{a}} \mathrm{CH}_{3}$ \\
\hline & $1476 \mathrm{sh}$ & 1476 & $\delta \mathrm{CH}_{2}(\mathrm{C} 17) \delta \mathrm{CH}_{2}(\mathrm{C} 14)$ & 1545 & $\delta \mathrm{CH}_{2}$ \\
\hline & & 1475 & $\delta \mathrm{CH}_{2}(\mathrm{C} 55) \delta \mathrm{CH}_{2}(\mathrm{C} 58)$ & 1544 & $\delta \mathrm{CH}_{2}$ \\
\hline & & 1474 & $\delta_{\mathrm{a}} \mathrm{CH}_{3}(\mathrm{C} 73)$ & 1542 & $\delta_{\mathrm{a}} \mathrm{CH}_{3}$ \\
\hline & & 1473 & $\delta_{\mathrm{a}} \mathrm{CH}_{3}(\mathrm{C} 26)$ & 1541 & $\delta_{\mathrm{a}} \mathrm{CH}_{3}$ \\
\hline \multirow[t]{13}{*}{$1472 w$} & & 1472 & $\delta_{\mathrm{a}} \mathrm{CH}_{3}(\mathrm{C} 51)$ & 1539 & $\delta_{\mathrm{a}} \mathrm{CH}_{3}$ \\
\hline & $1466 \mathrm{sh}$ & 1465 & $\delta_{\mathrm{a}} \mathrm{CH}_{3}(\mathrm{C} 51)$ & 1538 & $\delta_{\mathrm{a}} \mathrm{CH}_{3}$ \\
\hline & & 1465 & $\delta_{\mathrm{a}} \mathrm{CH}_{3}(\mathrm{C} 73)$ & 1534 & $\delta_{\mathrm{a}} \mathrm{CH}_{3}$ \\
\hline & & 1465 & $\delta \mathrm{CH}_{2}(\mathrm{C} 30) \delta \mathrm{CH}_{2}(\mathrm{C} 2)$ & 1532 & $\delta \mathrm{CH}_{2}$ \\
\hline & & 1464 & $\delta \mathrm{CH}_{2}(\mathrm{C} 8)$ & 1531 & $\delta \mathrm{CH}_{2}$ \\
\hline & & 1464 & $\delta_{\mathrm{a}} \mathrm{CH}_{3}(\mathrm{C} 26)$ & 1531 & $\delta_{\mathrm{a}} \mathrm{CH}_{3}$ \\
\hline & & 1462 & $\delta \mathrm{CH}_{2}(\mathrm{C} 36) \delta \mathrm{CH}_{2}(\mathrm{C} 39)$ & 1531 & $\delta \mathrm{CH}_{2}$ \\
\hline & & 1462 & $\delta \mathrm{CH}_{2}(\mathrm{C} 64)$ & 1531 & $\delta \mathrm{CH}_{2}$ \\
\hline & & 1461 & $\delta_{\mathrm{a}} \mathrm{CH}_{3}(\mathrm{C} 77)$ & 1530 & $\delta_{\mathrm{a}} \mathrm{CH}_{3}$ \\
\hline & & 1459 & $\delta \mathrm{CH}_{2}(\mathrm{C} 39) \delta \mathrm{CH}_{2}(\mathrm{C} 58)$ & 1530 & $\delta \mathrm{CH}_{2}$ \\
\hline & & 1457 & $\delta \mathrm{CH}_{2}(\mathrm{C} 33)$ & 1528 & $\delta \mathrm{CH}_{2}$ \\
\hline & & 1457 & $\delta \mathrm{CH}_{2}(\mathrm{C} 45)$ & 1526 & $\delta \mathrm{CH}_{2}$ \\
\hline & & 1454 & $\delta \mathrm{CH}_{2}(\mathrm{C} 2)$ & 1523 & $\delta \mathrm{CH}_{2}$ \\
\hline \multirow[t]{25}{*}{$1452 \mathrm{sh}$} & $1452 \mathrm{~m}$ & 1453 & $\delta \mathrm{CH}_{2}(\mathrm{C} 55) \delta \mathrm{CH}_{2}(\mathrm{C} 8)$ & 1520 & $\delta \mathrm{CH}_{2}$ \\
\hline & & 1450 & $\delta \mathrm{CH}_{2}(\mathrm{C} 70) \delta \mathrm{CH}_{2}(\mathrm{C} 48)$ & 1518 & $\delta \mathrm{CH}_{2}$ \\
\hline & & 1450 & $\delta \mathrm{CH}_{2}(\mathrm{C} 48)$ & 1518 & $\delta \mathrm{CH}_{2}$ \\
\hline & & 1450 & $\delta \mathrm{CH}_{2}(\mathrm{C} 70) \delta \mathrm{CH}_{2}(\mathrm{C} 23)$ & 1517 & $\delta \mathrm{CH}_{2}$ \\
\hline & & 1447 & $\delta \mathrm{CH}_{2}(\mathrm{C} 17) \delta \mathrm{CH}_{2}(\mathrm{C} 14)$ & 1517 & $\delta \mathrm{CH}_{2}$ \\
\hline & & 1447 & $\delta \mathrm{CH}_{2}(\mathrm{C} 67)$ & 1516 & $\delta \mathrm{CH}_{2}$ \\
\hline & & 1446 & $\delta \mathrm{CH}_{2}(\mathrm{C} 36) \delta \mathrm{CH}_{2}(\mathrm{C} 39)$ & 1515 & $\delta \mathrm{CH}_{2}$ \\
\hline & & 1446 & $\delta \mathrm{CH}_{2}(\mathrm{C} 61)$ & 1514 & $\delta \mathrm{CH}_{2}$ \\
\hline & & 1446 & $\delta \mathrm{CH}_{2}(\mathrm{C} 20) \delta \mathrm{CH}_{2}(\mathrm{C} 11)$ & 1514 & $\delta \mathrm{CH}_{2}$ \\
\hline & & 1441 & $\delta \mathrm{CH}_{2}(\mathrm{C} 5) \delta \mathrm{CH}_{2}(\mathrm{C} 30)$ & 1513 & $\delta \mathrm{CH}_{2}$ \\
\hline & 1434 sh & 1432 & wagCH ${ }_{2}(\mathrm{C} 30)$ & 1511 & wagCH $\mathrm{CH}_{2}$ \\
\hline & $1423 \mathrm{sh}$ & 1423 & $\rho \mathrm{CH}_{2}(\mathrm{C} 2)$ & 1498 & $\rho \mathrm{CH}_{2}$ \\
\hline & & 1407 & wagCH ${ }_{2}(\mathrm{C} 45)$ & 1473 & wagCH $\mathrm{CH}_{2}$ \\
\hline & & 1406 & wagCH$_{2}(\mathrm{C} 67)$ & 1443 & wagCH $\mathrm{CH}_{2}$ \\
\hline & & 1404 & wagCH $(\mathrm{C} 39) \mathrm{wagCH}_{2}(\mathrm{C} 42)$ & 1442 & wagCH $\mathrm{CH}_{2}$ \\
\hline & & 1402 & wagCH $2(\mathrm{C} 58)$ wagCH $_{2}(\mathrm{C} 61)$ & 1442 & wagCH $\mathrm{CH}_{2}$ \\
\hline & & 1401 & $\operatorname{wagCH}_{2}(\mathrm{C} 20)$ wagCH $_{2}(\mathrm{C} 11)$ & 1439 & wagCH $\mathrm{CH}_{2}$ \\
\hline & & 1395 & wagCH ${ }_{2}(\mathrm{C} 14)$ & 1436 & wagCH $\mathrm{CH}_{2}$ \\
\hline & & 1394 & $\delta_{\mathrm{s}} \mathrm{CH}_{3}(\mathrm{C} 77)$ & 1434 & $\delta_{\mathrm{s}} \mathrm{CH}_{3}$ \\
\hline & & 1388 & wagCH $2(\mathrm{C} 5)$ & 1429 & wagCH $\mathrm{CH}_{2}$ \\
\hline & & 1385 & $\delta_{\mathrm{s}} \mathrm{CH}_{3}(\mathrm{C} 73)$ & 1427 & $\delta_{\mathrm{s}} \mathrm{CH}_{3}$ \\
\hline & & 1383 & $\delta_{\mathrm{s}} \mathrm{CH}_{3}(\mathrm{C} 51)$ & 1427 & $\delta_{\mathrm{s}} \mathrm{CH}_{3}$ \\
\hline & & 1381 & $\delta_{\mathrm{s}} \mathrm{CH}_{3}(\mathrm{C} 26)$ & 1426 & $\delta_{\mathrm{s}} \mathrm{CH}_{3}$ \\
\hline & & 1372 & wagCH $\mathrm{CH}_{2}(\mathrm{C} 36)$ & 1421 & wagCH $\mathrm{CH}_{2}$ \\
\hline & & 1371 & wagCH $(\mathrm{C} 64) \mathrm{wagCH}_{2}(\mathrm{C} 70)$ & 1403 & wagCH $\mathrm{CH}_{2}$ \\
\hline
\end{tabular}




\begin{tabular}{|c|c|c|c|c|c|c|c|}
\hline \multirow[t]{2}{*}{$1357 \mathrm{~m}$} & \multirow[t]{2}{*}{$1354 \mathrm{sh}$} & & & 1359 & $\rho \mathrm{CH}_{2}(\mathrm{C} 5) \rho \mathrm{CH}_{2}(\mathrm{C} 30)$ & 1386 & $\rho \mathrm{CH}_{2}$ \\
\hline & & & & 1344 & wagCH ${ }_{2}(\mathrm{C} 33) \rho \mathrm{CH}_{2}(\mathrm{C} 36)$ & 1375 & wagCH${ }_{2}, \rho \mathrm{CH}_{2}$ \\
\hline \multirow[t]{4}{*}{ 1339sh } & & & & 1336 & wagCH $\mathrm{C}_{2}(\mathrm{C} 23)$ & 1373 & wagCH${ }_{2}$ \\
\hline & $1329 \mathrm{sh}$ & & & 1329 & wagCH ${ }_{2}(\mathrm{C} 2) \rho \mathrm{CH}_{2}(\mathrm{C} 55)$ & 1368 & wagCH ${ }_{2}, \rho \mathrm{CH}_{2}$ \\
\hline & & & & 1328 & wagCH $\mathrm{CH}_{2}(\mathrm{C} 48)$ & 1363 & wagCH $\mathrm{CH}_{2}$ \\
\hline & & & & 1324 & $\rho \mathrm{CH}_{2}(\mathrm{C} 58) \rho \mathrm{CH}_{2}(\mathrm{C} 61)$ & 1360 & $\rho \mathrm{CH}_{2}$ \\
\hline \multirow[t]{4}{*}{1318 sh } & & & & 1316 & $\rho \mathrm{CH}_{2}(\mathrm{C} 39) \rho \mathrm{CH}_{2}(\mathrm{C} 48)$ & 1358 & $\rho \mathrm{CH}_{2}$ \\
\hline & & & & 1316 & $\rho \mathrm{CH}_{2}(\mathrm{C} 67)$ & 1357 & $\rho \mathrm{CH}_{2}$ \\
\hline & & & & 1315 & $\rho \mathrm{CH}_{2}(\mathrm{C} 11)$ & 1353 & $\rho \mathrm{CH}_{2}$ \\
\hline & & & & 1314 & $\rho \mathrm{CH}_{2}(\mathrm{C} 45) \rho \mathrm{CH}_{2}(\mathrm{C} 42)$ & 1351 & $\rho \mathrm{CH}_{2}$ \\
\hline \multirow[t]{12}{*}{$1309 \mathrm{sh}$} & & & & 1310 & $\rho \mathrm{CH}_{2}(\mathrm{C} 23) \rho \mathrm{CH}_{2}(\mathrm{C} 8)$ & 1349 & $\rho \mathrm{CH}_{2}$ \\
\hline & $1305 w$ & & & 1307 & $\rho \mathrm{CH}_{2}(\mathrm{C} 70) \rho \mathrm{CH}_{2}(\mathrm{C} 64)$ & 1346 & $\rho \mathrm{CH}_{2}$ \\
\hline & & & & 1304 & $\rho \mathrm{CH}_{2}(\mathrm{C} 23) \rho \mathrm{CH}_{2}(\mathrm{C} 30)$ & 1346 & $\rho \mathrm{CH}_{2}$ \\
\hline & & & & 1297 & wagCH$_{2}(\mathrm{C} 67)$ wagCH $2(\mathrm{C} 55)$ & 1343 & wagCH $\mathrm{CH}_{2}$ \\
\hline & $1293 \mathrm{sh}$ & & & 1292 & $\rho \mathrm{CH}_{2}(\mathrm{C} 48) \rho \mathrm{CH}_{2}(\mathrm{C} 36)$ & 1337 & $\rho \mathrm{CH}_{2}$ \\
\hline & & & & 1285 & wagCH$_{2}(\mathrm{C} 8)$ & 1332 & wagCH $\mathrm{CH}_{2}$ \\
\hline & & & & 1280 & $\rho \mathrm{CH}_{2}(\mathrm{C} 14)$ & 1328 & $\rho \mathrm{CH}_{2}$ \\
\hline & & & & 1272 & $\rho \mathrm{CH}_{2}(\mathrm{C} 70)$ & 1313 & $\rho \mathrm{CH}_{2}$ \\
\hline & & & & 1265 & $\rho \mathrm{CH}_{2}(\mathrm{C} 30)$ & 1309 & $\rho \mathrm{CH}_{2}$ \\
\hline & $1253 \mathrm{sh}$ & & & 1263 & wagCH $\mathrm{CH}_{2}(\mathrm{C} 58)$ & 1303 & wagCH $\mathrm{CH}_{2}$ \\
\hline & & & & 1247 & $\rho \mathrm{CH}_{2}(\mathrm{C} 36)$ wagCH $\mathrm{CH}_{2}(\mathrm{C} 42)$ & 1302 & $\rho \mathrm{CH}_{2}$, wagCH \\
\hline & $1242 \mathrm{~m}$ & 1236 & $v_{\mathrm{a}} \mathrm{SO}_{2}(\mathrm{~S} 2)$ & 1237 & $\rho \mathrm{CH}_{2}(\mathrm{C} 20)$ & 1299 & $v_{\mathrm{a}} \mathrm{SO}_{2}(\mathrm{~S} 2)$ \\
\hline \multirow[t]{2}{*}{ 1230sh } & $1232 \mathrm{sh}$ & & & 1230 & $\operatorname{wagCH}_{2}(\mathrm{C} 14)$ & 1292 & wagCH$H_{2}$ \\
\hline & & & & 1226 & $\rho \mathrm{CH}_{2}(\mathrm{C} 33)$ & 1285 & $\rho \mathrm{CH}_{2}$ \\
\hline \multirow[t]{2}{*}{$1187 \mathrm{vs}$} & $1187 \mathrm{vw}$ & 1221 & $v_{\mathrm{a}} \mathrm{SO}_{2}(\mathrm{~S} 3)$ & 1220 & $\rho \mathrm{CH}_{2}(\mathrm{C} 64) \rho \mathrm{CH}_{2}(\mathrm{C} 67)$ & 1271 & $v_{\mathrm{a}} \mathrm{SO}_{2}(\mathrm{~S} 3)$ \\
\hline & & & & 1188 & $\rho^{\prime} \mathrm{CH}_{3}(\mathrm{C} 77)$ & 1269 & $\rho^{\prime} \mathrm{CH}_{3}$ \\
\hline $1177 \mathrm{sh}$ & & & & 1181 & $\rho \mathrm{CH}_{2}(\mathrm{C} 14)$ & 1267 & $\rho \mathrm{CH}_{2}$ \\
\hline $1168 \mathrm{sh}$ & & & & 1168 & $\rho \mathrm{CH}_{2}(\mathrm{C} 39)$ & 1258 & $\rho \mathrm{CH}_{2}$ \\
\hline \multirow[t]{2}{*}{$1140 \mathrm{~s}$} & & 1157 & $v_{\mathrm{s}} \mathrm{CF}_{3}(\mathrm{C} 9)$ & 1164 & $\rho \mathrm{CH}_{3}(\mathrm{C} 77)$ & 1254 & $v_{\mathrm{s}} \mathrm{CF}_{3}$ \\
\hline & $1134 w$ & 1150 & $v_{\mathrm{s}} \mathrm{CF}_{3}(\mathrm{C} 8)$ & 1143 & $\rho^{\prime} \mathrm{CH}_{3}(\mathrm{C} 77)$ & 1250 & $v_{s} \mathrm{CF}_{3}$ \\
\hline 1130sh & & 1124 & $v_{\mathrm{a}} \mathrm{CF}_{3}(\mathrm{C} 9)$ & 1128 & $\rho \mathrm{CH}_{3}(\mathrm{C} 51)$ & 1241 & $v_{\mathrm{a}} \mathrm{CF}_{3}$ \\
\hline \multirow[t]{4}{*}{$1126 \mathrm{sh}$} & $1122 \mathrm{sh}$ & 1120 & $v_{\mathrm{a}} \mathrm{CF}_{3}(\mathrm{C} 8)$ & 1126 & $\rho \mathrm{CH}_{3}(\mathrm{C} 51)$ & 1228 & $v_{\mathrm{a}} \mathrm{CF}_{3}$ \\
\hline & $1108 \mathrm{sh}$ & 1108 & $v_{\mathrm{a}} \mathrm{CF}_{3}(\mathrm{C} 9)$ & 1109 & $\rho \mathrm{CH}_{3}(\mathrm{C} 73)$ & 1217 & $v_{\mathrm{a}} \mathrm{CF}_{3}$ \\
\hline & & 1104 & $v_{\mathrm{a}} \mathrm{CF}_{3}(\mathrm{C} 8)$ & 1101 & $\rho \mathrm{CH}_{3}(\mathrm{C} 73)$ & 1206 & $v_{\mathrm{a}} \mathrm{CF}_{3}$ \\
\hline & 1094sh & & & 1096 & $\tau \mathrm{wCH} \mathrm{H}_{2}(\mathrm{C} 36)$ & 1159 & $\tau \mathrm{wCH} \mathrm{H}_{2}$ \\
\hline \multirow[t]{2}{*}{$1076 \mathrm{sh}$} & $1077 w$ & & & 1083 & $\rho^{\prime} \mathrm{CH}_{3}(\mathrm{C} 26)$ & 1149 & $\rho^{\prime} \mathrm{CH}_{3}$ \\
\hline & & & & 1063 & $v \mathrm{C} 2-\mathrm{C} 55$ & 1108 & $v \mathrm{C} 2-\mathrm{C} 55$ \\
\hline $1058 \mathrm{~s}$ & $1058 \mathrm{sh}$ & 1056 & $\mathrm{vS}_{\mathrm{a}} \mathrm{SO}_{2}(\mathrm{~S} 2)$ & 1059 & $v \mathrm{C} 5-\mathrm{C} 8$ & 1104 & $v \mathrm{~s}_{\mathrm{a}} \mathrm{SO}_{2}$ \\
\hline 1049sh & & & & 1050 & $v \mathrm{C} 61-\mathrm{C} 64 v \mathrm{C} 64-\mathrm{C} 67$ & 1092 & $v \mathrm{C}-\mathrm{C}$ \\
\hline \multirow[t]{2}{*}{$1044 \mathrm{sh}$} & $1042 \mathrm{sh}$ & 1041 & $v_{\mathrm{a}} \mathrm{SO}_{2}(\mathrm{~S} 3)$ & 1042 & $v \mathrm{C} 36-\mathrm{C} 39 v \mathrm{C} 39-\mathrm{C} 42$ & 1086 & $v \mathrm{~s}_{\mathrm{a}} \mathrm{SO}_{2}$ \\
\hline & & & & 1039 & $v \mathrm{C} 45-\mathrm{C} 48 v \mathrm{C} 42-\mathrm{C} 45 v \mathrm{C} 48-\mathrm{C} 51$ & 1082 & $v \mathrm{C}-\mathrm{C}$ \\
\hline \multirow[t]{2}{*}{$1037 \mathrm{sh}$} & & & & 1037 & vC58-C61 & 1078 & $v \mathrm{C}-\mathrm{C}$ \\
\hline & & & & 1034 & vC17-C20 & 1076 & $v \mathrm{C}-\mathrm{C}$ \\
\hline \multirow[t]{4}{*}{ 1030sh } & & & & 1029 & 8С $33 \mathrm{C} 36 \mathrm{C} 39$ & 1075 & $8 \mathrm{C} 33 \mathrm{C} 36 \mathrm{C} 39$ \\
\hline & & & & 1026 & $v \mathrm{C} 11-\mathrm{C} 14 v \mathrm{C} 14-\mathrm{C} 17$ & 1072 & $v \mathrm{C}-\mathrm{C}$ \\
\hline & & & & 1025 & $v \mathrm{C} 67-\mathrm{C} 70$ & 1071 & $v \mathrm{C}-\mathrm{C}$ \\
\hline & & & & 1013 & $v \mathrm{C} 30-\mathrm{C} 33$ & 1060 & $v \mathrm{C}-\mathrm{C}$ \\
\hline
\end{tabular}




\begin{tabular}{|c|c|c|c|c|c|c|c|}
\hline & & & & 1013 & $v \mathrm{C} 70-\mathrm{C} 73$ & 1056 & $v \mathrm{C}-\mathrm{C}$ \\
\hline & & & & 1008 & vC55-C58 & 1052 & $v \mathrm{C}-\mathrm{C}$ \\
\hline & & & & 1005 & $v \mathrm{C} 8-\mathrm{C} 11 v \mathrm{C} 23-\mathrm{C} 26$ & 1048 & $v \mathrm{C}-\mathrm{C}$ \\
\hline & $1000 \mathrm{sh}$ & & & 1000 & vC55-C58 & 1029 & $v \mathrm{C}-\mathrm{C}$ \\
\hline & & & & 988 & $v \mathrm{C} 5-\mathrm{C} 8$ & 1022 & $v \mathrm{C}-\mathrm{C}$ \\
\hline & & & & 981 & vC58-C61 & 1016 & $v \mathrm{C}-\mathrm{C}$ \\
\hline & & & & 977 & $v_{\mathrm{a}} \mathrm{NC}_{3}$ & 1010 & $v_{\mathrm{a}} \mathrm{NC}_{3}$ \\
\hline & & 970 & $v \mathrm{~S} 2-\mathrm{N} 1$ & 970 & vC17-C20 & 1006 & $v_{\mathrm{a}} \mathrm{S}-\mathrm{N}$ \\
\hline & $962 \mathrm{vw}$ & & & 958 & vN1-C77 & 1002 & $v \mathrm{~N}-\mathrm{C}$ \\
\hline & & & & 933 & vC61-C64 & 987 & $v \mathrm{C}-\mathrm{C}$ \\
\hline & 924sh & & & 926 & $v_{\mathrm{a}} \mathrm{NC}_{3}$ & 982 & $v_{\mathrm{a}} \mathrm{NC}_{3}$ \\
\hline & & & & 920 & $v \mathrm{C} 33-\mathrm{C} 36 \rho^{\prime} \mathrm{CH}_{3}(\mathrm{C} 51)$ & 977 & $v \mathrm{C}-\mathrm{C}, \rho^{\prime} \mathrm{CH}_{3}$ \\
\hline $895 \mathrm{vw}$ & & & & 893 & $\rho \mathrm{CH}_{3}(\mathrm{C} 73) \vee \mathrm{C} 67-\mathrm{C} 70$ & 935 & $\rho \mathrm{CH}_{3}, v \mathrm{C}-\mathrm{C}$ \\
\hline & $887 w$ & & & 885 & $\rho \mathrm{CH}_{3}(\mathrm{C} 51)$ & 928 & $\rho \mathrm{CH}_{3}$ \\
\hline & & & & 881 & $\rho \mathrm{CH}_{3}(\mathrm{C} 26) v \mathrm{C} 20-\mathrm{C} 23$ & 906 & $\rho \mathrm{CH}_{3}, \nu \mathrm{C}-\mathrm{C}$ \\
\hline $874 \mathrm{vw}$ & $870 w$ & & & 872 & $\rho \mathrm{CH}_{3}(\mathrm{C} 51)$ & 898 & $\rho \mathrm{CH}_{3}$ \\
\hline & & & & 865 & $\rho^{\prime} \mathrm{CH}_{3}(\mathrm{C} 73)$ & 891 & $\rho^{\prime} \mathrm{CH}_{3}$ \\
\hline & & & & 858 & $\tau \mathrm{wCH}_{2}(\mathrm{C} 20)$ & 880 & $\tau \mathrm{wCH} \mathrm{w}_{2}$ \\
\hline & $845 w$ & & & 844 & $\mathrm{v}_{\mathrm{a}} \mathrm{NC}_{3}$ & 849 & $v_{\mathrm{a}} \mathrm{NC}_{3}$ \\
\hline & & & & 835 & $\tau \mathrm{wCH}_{2}(\mathrm{C} 20) \tau \mathrm{wCH}_{2}(\mathrm{C} 14)$ & 818 & $\tau \mathrm{wCH}_{2}$ \\
\hline & & & & 825 & $\tau \mathrm{wCH}_{2}(\mathrm{C} 36)$ & 809 & $\tau \mathrm{wCH}_{2}$ \\
\hline $790 w$ & 811 & & & 801 & $\mathrm{~V}_{\mathrm{a}} \mathrm{NC}_{3}$ & 798 & $\mathrm{~V}_{\mathrm{a}} \mathrm{NC}_{3}$ \\
\hline $765 \mathrm{vw}$ & $760 \mathrm{vw}$ & & & 758 & $v_{\mathrm{s}} \mathrm{NC}_{3}$ & 783 & $v_{\mathrm{s}} \mathrm{NC}_{3}$ \\
\hline $741 w$ & $737 \mathrm{~s}$ & 732 & $\delta_{\mathrm{s}} \mathrm{CF}_{3}(\mathrm{C} 9)$ & 732 & $\tau \mathrm{wCH}_{2}(\mathrm{C} 64)$ & 778 & $\delta_{\mathrm{s}} \mathrm{CF}_{3}$ \\
\hline 730sh & & & & 730 & $\tau \mathrm{wCH}{ }_{2}(\mathrm{C} 30) \tau \mathrm{wCH} \mathrm{w}_{2}(\mathrm{C} 36)$ & 769 & $\tau \mathrm{wCH} \mathrm{w}_{2}$ \\
\hline $716 \mathrm{sh}$ & $725 \mathrm{sh}$ & 723 & $\delta_{\mathrm{s}} \mathrm{CF}_{3}(\mathrm{C} 8)$ & 725 & $\tau \mathrm{wCH}_{2}(\mathrm{C} 5)$ & 760 & $\delta_{\mathrm{s}} \mathrm{CF}_{3}$ \\
\hline & & & & 706 & $\tau \mathrm{wCH}(\mathrm{C} 2) \tau \mathrm{wCH}_{2}(\mathrm{C} 61)$ & 746 & $\tau \mathrm{wCH} \mathrm{W}_{2}$ \\
\hline & & & & 702 & $\tau \mathrm{wCH} \mathrm{H}_{2}(\mathrm{C} 33) \tau \mathrm{wCH} \mathrm{H}_{2}(\mathrm{C} 30)$ & 744 & $\tau \mathrm{wCH}_{2}$ \\
\hline & & 684 & vS3-N1 & 686 & $\tau \mathrm{wCH}_{2}(\mathrm{C} 23) \tau \mathrm{wCH}_{2}(\mathrm{C} 20)$ & 743 & $\tau \mathrm{wCH}_{2}$ \\
\hline & & & & 675 & $\tau \mathrm{wCH}_{2}(\mathrm{C} 58) \tau \mathrm{wCH} \mathrm{H}_{2}(\mathrm{C} 55)$ & 739 & $\tau \mathrm{wCH}_{2}$ \\
\hline & & & & 671 & $\tau \mathrm{wCH}_{2}(\mathrm{C} 48)$ & 735 & $\tau \mathrm{wCH}_{2}$ \\
\hline & & & & 669 & $\tau \mathrm{wCH}(\mathrm{C} 11) \tau \mathrm{wCH}_{2}(\mathrm{C} 8)$ & 714 & $v_{\mathrm{s}} \mathrm{S}-\mathrm{N}$ \\
\hline & & 616 & wagSO $_{2}(\mathrm{~S} 3)$ & 663 & $\tau \mathrm{wCH}_{2}(\mathrm{C} 67) \tau \mathrm{wCH} \mathrm{H}_{2}(\mathrm{C} 70)$ & 648 & wagSO$_{2}$ \\
\hline $655 w$ & & 568 & wagSO $_{2}(\mathrm{~S} 2)$ & 660 & $\tau \mathrm{wCH}_{2}(\mathrm{C} 42) \tau \mathrm{wCH}(\mathrm{C} 39)$ & 587 & wagSO$_{2}$ \\
\hline $618 \mathrm{~s}$ & $584 \mathrm{vw}$ & 550 & $\delta_{\mathrm{a}} \mathrm{CF}_{3}(\mathrm{C} 9)$ & 585 & $8 \mathrm{C} 8 \mathrm{C} 5 \mathrm{~N} 18 \mathrm{~N} 1 \mathrm{C} 30 \mathrm{C} 33$ & 560 & $\delta_{\mathrm{a}} \mathrm{CF}_{3}$ \\
\hline & $565 \mathrm{vw}$ & 540 & $\delta_{\mathrm{a}} \mathrm{CF}_{3}(\mathrm{C} 9)$ & 533 & $\delta \mathrm{N} 1 \mathrm{C} 2 \mathrm{C} 55$ \&C58C61C64 & 554 & $\delta_{\mathrm{a}} \mathrm{CF}_{3}$ \\
\hline & $547 \mathrm{vw}$ & 538 & $\delta_{\mathrm{a}} \mathrm{CF}_{3}(\mathrm{C} 8)$ & 509 & $\delta_{\mathrm{a}} \mathrm{NC}_{3}$ & 548 & $\delta_{\mathrm{a}} \mathrm{CF}_{3}$ \\
\hline & $507 \mathrm{vw}$ & 528 & $\delta_{\mathrm{a}} \mathrm{CF}_{3}(\mathrm{C} 8)$ & 499 & $\delta \mathrm{C} 36 \mathrm{C} 39 \mathrm{C} 42$ & 534 & $\delta_{\mathrm{a}} \mathrm{CF}_{3}$ \\
\hline & & 497 & $\delta \mathrm{SO}_{2}(\mathrm{~S} 3)$ & 475 & $\delta \mathrm{C} 36 \mathrm{C} 39 \mathrm{C} 42$ & 508 & $\delta \mathrm{SO}_{2}$ \\
\hline & & 483 & $\delta \mathrm{SO}_{2}(\mathrm{~S} 2)$ & 460 & $\delta_{\mathrm{s}} \mathrm{NC}_{3}$ & 490 & $\delta \mathrm{SO}_{2}$ \\
\hline & $436 \mathrm{vw}$ & & & 433 & $\delta \mathrm{C} 33 \mathrm{C} 36 \mathrm{C} 39 \delta \mathrm{C} 45 \mathrm{C} 48 \mathrm{C} 51$ & 487 & $\delta \mathrm{CCC}$ \\
\hline & & & & 428 & $\delta \mathrm{C} 2 \mathrm{C} 55 \mathrm{C} 58$ & 475 & $\delta \mathrm{CCC}$ \\
\hline & $413 \mathrm{sh}$ & & & 416 & $\tau \mathrm{C} 11-\mathrm{C} 14$ & 444 & $\tau \mathrm{C}-\mathrm{C}$ \\
\hline & $399 w$ & 409 & $\tau_{\mathrm{w}} \mathrm{SO}_{2}(\mathrm{~S} 3)$ & 396 & $\delta \mathrm{C} 67 \mathrm{C} 70 \mathrm{C} 738 \mathrm{C} 61 \mathrm{C} 64 \mathrm{C} 67$ & 440 & $\tau_{\mathrm{w}} \mathrm{SO}_{2}$ \\
\hline & 378 sh & & & 373 & $\delta \mathrm{C} 30 \mathrm{C} 33 \mathrm{C} 36$ & 400 & $\delta \mathrm{CCC}$ \\
\hline & & 366 & $\tau_{\mathrm{w}} \mathrm{SO}_{2}(\mathrm{~S} 2)$ & 360 & $\delta \mathrm{C} 42 \mathrm{C} 45 \mathrm{C} 48$ & 388 & $\tau_{\mathrm{w}} \mathrm{SO}_{2}$ \\
\hline & & 331 & $\rho \mathrm{SO}_{2}(\mathrm{~S} 3)$ & 359 & $\rho^{\prime} \mathrm{NC}_{3}$ & 337 & $\rho \mathrm{SO}_{2}$ \\
\hline & $342 \mathrm{sh}$ & 310 & $\rho \mathrm{CF}_{3}(\mathrm{C} 9)$ & 341 & $\delta_{\mathrm{a}} \mathrm{NC}_{3} \delta_{\mathrm{a}} \mathrm{NC}_{3}$ & 319 & $\rho \mathrm{CF}_{3}$ \\
\hline & $328 \mathrm{sh}$ & 303 & $\rho \mathrm{CF}_{3}(\mathrm{C} 8)$ & 335 & $\delta_{\mathrm{a}} \mathrm{NC}_{3}$ & 315 & $\rho \mathrm{CF}_{3}$ \\
\hline
\end{tabular}




\begin{tabular}{|c|c|c|c|c|c|c|}
\hline $304 w$ & 284 & $\rho \mathrm{SO}_{2}(\mathrm{~S} 2)$ & 278 & $\delta \mathrm{C} 11 \mathrm{C} 14 \mathrm{C} 17 \delta \mathrm{C} 20 \mathrm{C} 23 \mathrm{C} 26$ & 289 & $\rho \mathrm{SO}_{2}$ \\
\hline $227 \mathrm{~m}$ & 259 & vS3-C9 & 269 & $8 \mathrm{C} 55 \mathrm{C} 58 \mathrm{C} 61$ & 274 & $v S-C$ \\
\hline \multirow[t]{7}{*}{$258 \mathrm{sh}$} & 252 & $v \mathrm{~S} 2-\mathrm{C} 8$ & 248 & $8 \mathrm{C} 36 \mathrm{C} 39 \mathrm{C} 42 \tau \mathrm{C} 30-\mathrm{C} 33$ & 263 & $\rho \mathrm{CF}_{3}$ \\
\hline & & & 240 & $\tau_{\mathrm{w}} \mathrm{CH}_{3}(\mathrm{C} 77)$ & 255 & $\tau_{\mathrm{w}} \mathrm{CH}_{3}$ \\
\hline & & & 228 & $\tau \mathrm{C} 61-\mathrm{C} 64$ & 254 & $\tau_{\mathrm{w}} \mathrm{CH}_{3}$ \\
\hline & & & 225 & $\tau_{\mathrm{w}} \mathrm{CH}_{3}(\mathrm{C} 51) \delta \mathrm{C} 33 \mathrm{C} 36 \mathrm{C} 39$ & 250 & $\tau_{\mathrm{w}} \mathrm{CH}_{3}$ \\
\hline & & & 223 & $\tau_{\mathrm{w}} \mathrm{CH}_{3}(\mathrm{C} 26)$ & 247 & $\tau \mathrm{C}-\mathrm{C}$ \\
\hline & & & 223 & $\tau_{\mathrm{w}} \mathrm{CH}_{3}(\mathrm{C} 51)$ & 230 & $\tau \mathrm{C}-\mathrm{C}$ \\
\hline & & & 213 & $\tau_{\mathrm{w}} \mathrm{CH}_{3}(\mathrm{C} 73)$ & 203 & $\tau \mathrm{C}-\mathrm{C}$ \\
\hline \multirow[t]{3}{*}{$203 \mathrm{sh}$} & & & 197 & $\tau \mathrm{C} 14-\mathrm{C} 17$ & 201 & $\tau \mathrm{C}-\mathrm{C}$ \\
\hline & 187 & $\rho^{\prime} \mathrm{CF}_{3}(\mathrm{C} 9)$ & 195 & $\tau \mathrm{C} 58-\mathrm{C} 618 \mathrm{C} 64 \mathrm{C} 67 \mathrm{C} 70$ & 198 & $\rho^{\prime} \mathrm{CF}_{3}$ \\
\hline & 186 & $\rho^{\prime} \mathrm{CF}_{3}(\mathrm{C} 8)$ & 183 & $\delta \mathrm{C} 17 \mathrm{C} 20 \mathrm{C} 23$ & 195 & $\tau_{\mathrm{w}} \mathrm{CH}_{3}$ \\
\hline $173 \mathrm{sh}$ & 163 & $\delta \mathrm{N} 1 \mathrm{~S} 3 \mathrm{C} 9$ & 172 & $\tau \mathrm{C} 33-\mathrm{C} 36$ & 168 & $\delta \mathrm{SNS}$ \\
\hline \multirow[t]{3}{*}{$156 \mathrm{sh}$} & 149 & $\delta \mathrm{N} 1 \mathrm{~S} 2 \mathrm{C} 8$ & 158 & $\tau \mathrm{C} 5-\mathrm{C} 8$ & 146 & $\tau \mathrm{C}-\mathrm{C}$ \\
\hline & & & 137 & $\tau \mathrm{C} 39-\mathrm{C} 42$ & 141 & $\tau \mathrm{C}-\mathrm{C}$ \\
\hline & & & 132 & $\tau \mathrm{C} 45-\mathrm{C} 48$ & 134 & $\tau \mathrm{C}-\mathrm{C}$ \\
\hline \multirow[t]{2}{*}{$121 \mathrm{sh}$} & & & 118 & $\tau \mathrm{C} 42-\mathrm{C} 45$ & 122 & $\tau \mathrm{C}-\mathrm{C}$ \\
\hline & & & 112 & $\tau \mathrm{C} 67-\mathrm{C} 70$ & 116 & $\tau \mathrm{C}-\mathrm{C}$ \\
\hline \multirow[t]{4}{*}{$109 \mathrm{w}$} & & & 109 & $\tau \mathrm{C} 8-\mathrm{C} 11$ & 113 & $\tau \mathrm{C}-\mathrm{C}$ \\
\hline & 100 & $\delta \mathrm{S} 2 \mathrm{~N} 1 \mathrm{~S} 3$ & 105 & $\tau \mathrm{C} 2-\mathrm{C} 55 \tau \mathrm{C} 30-\mathrm{C} 33$ & 105 & $\tau \mathrm{SNO}$ \\
\hline & & & 99 & $\tau \mathrm{C} 5-\mathrm{C} 8 \tau \mathrm{C} 30-\mathrm{C} 33$ & 96 & $\tau \mathrm{C}-\mathrm{C}$ \\
\hline & & & 95 & $\tau \mathrm{C} 5-\mathrm{C} 8 \tau \mathrm{C} 2-\mathrm{C} 55$ & 84 & $\tau \mathrm{C}-\mathrm{C}$ \\
\hline $87 \mathrm{sh}$ & & & 88 & $\tau \mathrm{C} 5-\mathrm{C} 8 \tau \mathrm{C} 8-\mathrm{C} 11$ & 76 & $\tau \mathrm{C}-\mathrm{C}$ \\
\hline \multirow[t]{2}{*}{$76 \mathrm{sh}$} & & & 78 & $\tau \mathrm{C} 11-\mathrm{C} 14 \tau \mathrm{C} 5-\mathrm{C} 8$ & 73 & $\tau \mathrm{C}-\mathrm{C}$ \\
\hline & & & 74 & $\tau \mathrm{C} 20-\mathrm{C} 23$ & 69 & $\tau \mathrm{C}-\mathrm{C}$ \\
\hline \multirow[t]{2}{*}{$63 \mathrm{sh}$} & 60 & $\tau \mathrm{S} 2-\mathrm{N} 1$ & 62 & $\tau \mathrm{C} 30-\mathrm{C} 33$ & 66 & $\tau \mathrm{C}-\mathrm{C}$ \\
\hline & & & 55 & $\tau \mathrm{C} 64-\mathrm{C} 67$ & 63 & $\tau \mathrm{C}-\mathrm{C}$ \\
\hline \multirow[t]{2}{*}{$49 \mathrm{~s}$} & & & 48 & $\tau \mathrm{C} 58-\mathrm{C} 61 \tau_{\mathrm{w}} \mathrm{NC}_{3}$ & 53 & $\tau \mathrm{C}-\mathrm{C}, \tau_{\mathrm{w}} \mathrm{NC}_{3}$ \\
\hline & & & 45 & $\tau \mathrm{C} 36-\mathrm{C} 39$ & 47 & $\tau \mathrm{C} 36-\mathrm{C} 39$ \\
\hline \multirow[t]{2}{*}{$34 \mathrm{sh}$} & 38 & $\tau_{\mathrm{w}} \mathrm{CF}_{3}(\mathrm{C} 9)$ & 40 & $\tau \mathrm{C} 17-\mathrm{C} 20$ & 45 & $\tau_{\mathrm{w}} \mathrm{CF}_{3}$ \\
\hline & 30 & $\tau_{\mathrm{w}} \mathrm{CF}_{3}(\mathrm{C} 8)$ & 30 & $\tau \mathrm{C} 58-\mathrm{C} 61 \tau \mathrm{C} 5-\mathrm{C} 8$ & 42 & $\tau_{\mathrm{w}} \mathrm{CF}_{3}$ \\
\hline $15 \mathrm{sh}$ & 5 & $\tau \mathrm{S} 3-\mathrm{N} 1$ & 18 & $\tau_{\mathrm{w}} \mathrm{NC}_{3} \tau \mathrm{C} 2-\mathrm{C} 55$ & 7 & $\tau \mathrm{S}-\mathrm{N}$ \\
\hline
\end{tabular}

Abbreviations: $v$, stretching; wag, wagging; $\tau$, torsion; $\rho$, rocking; $\tau_{\mathrm{w}}$, twisting; $\delta$, deformation; a, antisymmetric; $\mathrm{s}$, symmetric; ${ }^{a}$ This work, ${ }^{b}$ From scaled quantum mechanical force field with B3LYP/6-311++ $\mathrm{G}^{* *}$ method, ${ }^{\mathrm{c}}$ From scaled quantum mechanical force field with B3LYP/6-31G* method; ${ }^{\text {From B }}$ LYP/6-31G* method.

\subsubsection{Bands assignments}

4.7.1.1. 4000-2000 $\mathrm{cm}^{-1}$ region. In this region, no bands of the anion are expected and only vibartional bands for the cation and the IL are predicted. The anti-symmetric and symmetric stretching modes of $\mathrm{CH}_{2}$ and $\mathrm{CH}_{3}$ groups are expected in this region. In the [Aliquat $\left.{ }^{+}\right]\left[\mathrm{Cl}^{-}\right] \mathrm{IL}$ the terminal $\mathrm{CH}_{3}$ experimental anti-symmetric stretching band was observed at $2954 \mathrm{~cm}^{-1}$ and in $\left[\right.$ Aliquat $\left.{ }^{+}\right]\left[\mathrm{NTf}_{2}^{-}\right]$at $2956 \mathrm{~cm}^{-1}$, respectively $[68,69]$. Here, this IL has four terminal $\mathrm{CH}_{3}$ groups (C26, C51, C73, C77) where three of them belong to larges side chains (C26, C51, $\mathrm{C73}$ ) and the remains belong to $\mathrm{N}-\mathrm{CH}_{3}$ group (C77). The SQMFF calculations predict the two anti-symmetric modes of latter group at higher wavenumbers than the other ones and, for 
these reasons, the very weak Raman band at $3051 \mathrm{~cm}^{-1}$ is assigned to those vibration modes. The anti-symmetric stretching modes for the other $\mathrm{CH}_{3}$ groups are predicted mixed with the anti-symmetric modes of $\mathrm{CH}_{2}$ groups. The detailed assignments of these groups taking into account the SQM calculations can be seen in Table 3.

4.7.1.2. 1500-1000 $\mathrm{cm}^{-1}$ region. In this region the vibration modes of anion, cation and IL appear. Thus, the anti-symmetric $\mathrm{SO}_{2}$ stretching modes of both groups are predicted at 1236 and $1221 \mathrm{~cm}^{-1}$ and, hence, the Raman and IR bands respectively at 1242 and $1187 \mathrm{~cm}^{-1}$ are assigned to those two vibration modes. The corresponding symmetric modes are predicted at 1056 and $1041 \mathrm{~cm}^{-1}$ and assigned respectively to the band and shoulder located at 1058 and $1044 \mathrm{~cm}^{-1}$. In the IL, the anti-symmetric modes are predicted at 1299 and $1271 \mathrm{~cm}^{-1}$ while the symmetric ones at 1104 and $1086 \mathrm{~cm}^{-1}$. The six anti-symmetric and symmetric stretching modes of two $\mathrm{CF}_{3}$ groups are predicted by SQM calculations between 1157 and $1104 \mathrm{~cm}^{-1}$ while in the IL these modes are predicted between 1254 and $1206 \mathrm{~cm}^{-1}$. Hence, the IR and Raman bands observed in that region are easily assigned to those stretching modes. In this region, for the cation the deformation, wagging and rocking modes of $\mathrm{CH}_{2}$ groups and, the anti-symmetric and symmetric deformation and rocking modes of $\mathrm{CH}_{3}$ groups are expected. The deformation modes of both groups appear mixed among them in the region between 1496 and $1381 \mathrm{~cm}^{-1}$, thus, the bands and shoulders observed in that region can be assigned to those deformation modes. The wagging modes of $\mathrm{CH}_{2}$ groups are predicted from 1432 up to 1230 $\mathrm{cm}^{-1}$ while the rocking modes between 1423 and $1168 \mathrm{~cm}^{-1}$ and, hence, those two vibration modes can be assigned, as predicted the SQM calculations and according assignments for similar species $[34,37,38]$. The rocking modes of $\mathrm{CH}_{3}$ groups in the cation are predicted in this region between 1188 and $1083 \mathrm{~cm}^{-1}$ while in the IL between 1269 and $1149 \mathrm{~cm}^{-1}$. Other rocking modes in the cation are also predicted between 920 and $865 \mathrm{~cm}^{-1}$ and in the IL between 977 and $891 \mathrm{~cm}^{-1}$. Therefore, the IR and Raman bands and shoulders located in those regions are assigned to those rocking modes. Note that in this region are also predicted C-C stretching modes and CCC deformation modes.

4.7.1.3. 1000-10 $\mathrm{cm}^{-1}$ region. In this region the $\mathrm{C}-\mathrm{C}$ and $\mathrm{N}-\mathrm{C}$ stretching modes of cation and IL and the S-N stretching modes of anion are expected. Besides, the deformation, rocking and twisting modes of $\mathrm{SO}_{2}$ groups and deformation modes of $\mathrm{CF}_{3}$ groups of anion are predicted in this region together with the twisting modes of $\mathrm{CH}_{2}$ and $\mathrm{CH}_{3}$ groups of cation. The $\mathrm{N}-\mathrm{CH}_{3}$ stretching mode is predicted in the anion at $958 \mathrm{~cm}^{-1}$ and at $1002 \mathrm{~cm}^{-1}$ in the IL. Hence, the weak Raman band at $962 \mathrm{~cm}^{-1}$ is assigned to that vibration mode of both species. The S-N stretching mode is predicted in the anion at $684 \mathrm{~cm}^{-1}$ while in IL at $714 \mathrm{~cm}^{-1}$. Hence, the IR and 
Raman bands at 655 and $737 \mathrm{~cm}^{-1}$ respectively can be assigned to the symmetric deformation of $\mathrm{CF}_{3}$ group and to the wagging mode of $\mathrm{SO}_{2}$ group of anion and IL, respectively [70]. Both bands can also be simultaneously assigned to $\mathrm{CH}_{2}$ twisting modes of cation. As reported in literature, the medium band around $790 \mathrm{~cm}^{-1}$ can be assigned to vibrations related to the N-C group [71].The strong band at $618 \mathrm{~cm}^{-1}$ is attributed to anti-symmetric deformation of $\mathrm{CF}_{3}$ group of anion and IL. The deformation, rocking and twisting modes of $\mathrm{SO}_{2}$ groups are assigned as predicted by calculations at 497/483, 331/284 and 409/366 $\mathrm{cm}^{-1}$ while the deformation and rocking modes of $\mathrm{CF}_{3}$ groups can be assigned to the bands located between $550 / 528$ and $310 / 303 \mathrm{~cm}^{-1}$, respectively.

\subsection{Force Fields}

The harmonic force fields calculated with the SQMFF methodology and the Molvib program, for the anion of IL with the B3LYP/6-311++G** method and for its cation with the B3LYP/6-31G* level of theory, have allowed the determination of scaled force constants for those two species of IL in gas phase. These parameters are important to characterize the force of different bonds.In Table 4 the results of main force constants are compared with those reported for the [BMIM][OTF] IL and its cationic and anionic species [38].

Table 4. Scaled internal force constants for cation and anion of [Aliquat $\left.{ }^{+}\right]\left[\mathrm{NTf}_{2}^{-}\right.$] in gas phase by using the B3LYP method and different basis sets.

\begin{tabular}{|c|c|c|c|}
\hline \multicolumn{4}{|c|}{ B3LYP Method } \\
\hline \multicolumn{4}{|c|}{$6-311++\mathrm{G}^{* *}$} \\
\hline Force constants & {$\left[\mathrm{NTf}_{2}^{-}\right]^{\mathrm{a}}$} & {$[\mathrm{OTF}]^{\mathrm{b}}$} & {$[\mathrm{BMIM}][\mathrm{OTF}]^{\mathrm{b}}$} \\
\hline$f\left(v \mathrm{SO}_{2}\right)$ & 8.20 & 7.63 & 7.65 \\
\hline$f\left(v C F_{3}\right)$ & 5.31 & 4.98 & 5.20 \\
\hline$f(v S-C)$ & 2.16 & 2.03 & 2.21 \\
\hline$f(v S-N)$ & 4.56 & & \\
\hline$f\left(\mathrm{SSO}_{2}\right)$ & 1.93 & 1.62 & 1.82 \\
\hline$f\left(\delta C F_{3}\right)$ & 1.51 & 1.54 & 1.23 \\
\hline$f(\delta S-N-S)$ & 0.79 & & \\
\hline \multirow[t]{2}{*}{ Force constants } & $6-31 \mathrm{G}^{*}$ & \multicolumn{2}{|c|}{$6-311++\mathrm{G}^{* *}$} \\
\hline & [Aliquat $\left.^{+}\right]^{\mathrm{a}}$ & {$[\mathrm{BMIM}]^{\mathrm{b}}$} & {$[\mathrm{BMIM}][\mathrm{OTF}]^{\mathrm{b}}$} \\
\hline$f\left(v N-\mathrm{CH}_{3}\right)$ & 3.95 & 4.40 & 5.06 \\
\hline$f\left(\nu \mathrm{CH}_{2}\right)$ & 4.75 & 4.73 & 4.73 \\
\hline$f\left(v \mathrm{CH}_{3}\right)$ & 4.91 & 4.87 & 4.84 \\
\hline$f\left(\delta \mathrm{CH}_{2}\right)$ & 0.79 & 0.77 & 1.28 \\
\hline $\mathrm{f}\left(\mathrm{\delta CH}_{3}\right)$ & 0.56 & 0.52 & 0.54 \\
\hline
\end{tabular}

Analyzing first the force constants of anionic species of both ILs, we observed higher values in the $f\left(v \mathrm{SO}_{2}\right)$ and $f\left(v_{C F}\right)$ force constants, as expected because the [NTf ${ }_{2}^{-}$anion presents two 
$\mathrm{SO}_{2}$ and two $\mathrm{CF}_{3}$ groups while [OTF] has only one $\mathrm{SO}_{3}$ and one $\mathrm{CF}_{3}$ group [38]. However, the values of those two force constants increase in the [BMIM][OTF] IL. Comparing now the cationic species of both ILs, it is observed that despite of three long side chains present in [Aliquat ${ }^{+}$the values of all force constants are practically the same and only a slight lower value is observed in the $f\left(v N-C_{3}\right)$ force constant. This minimum difference could be explained in [Aliquat ${ }^{+}$] because the $\mathrm{N}$ atom of group is not linked to a ring, as in [BMIM] [38]. In the [BMIM] $\left[\mathrm{NO}_{3}\right] \mathrm{IL}$, the value of the $f\left(v N-\mathrm{CH}_{3}\right)$ force constant is 4.70 mdyn $\AA^{-1}$ [37] while in the free base of alkaloids as scopolamine, the value is 4.76 mdyn $\AA^{-1}$ and, in heroin and morphine the value increase at 4.83 mdyn $\AA^{-1}$ [72-74]. In all those alkaloids, the $\mathrm{N}$ atom of $\mathrm{N}-\mathrm{CH}_{3}$ group is part of a ring. 


\section{Conclusions}

[Aliquat $\left.{ }^{+}\right]\left[\mathrm{NTf}_{2}^{-}\right]$IL is successfully synthesized by anionic exchange of [Aliquat $\left.{ }^{+}\right]\left[\mathrm{Cl}^{-}\right]$. Its structure was confirmed by ${ }^{1} \mathrm{H}-\mathrm{NMR},{ }^{13} \mathrm{C}-\mathrm{NMR}$, and ${ }^{19} \mathrm{~F}-\mathrm{NMR}$ spectroscopy and characterized it by infrared and Raman spectroscopies. The thermal stability of this IL was investigated by TGA and DTA measurements. The thermal behaviour indicated that [Aliquat $\left.{ }^{+}\right]\left[\mathrm{NTf}_{2}{ }^{-}\right]$is stable up to $483^{\circ} \mathrm{C}$. The structures of cation and IL were determined by theoretical B3LYP/6-31G* calculations while the anionic species was optimized by using the B3LYP/6-311++G** level of theory. A hexadentate coordination geometry between cationanion was predicted by atoms in molecules (AIM) studies for the [Aliquat $\left.{ }^{+}\right]\left[\mathrm{NTf}_{2}^{-}\right]$IL by using B3LYP/6-31G* calculations where three $\mathrm{O}$ atoms of anion are linked to six $\mathrm{H}$ atoms of cation by $\mathrm{S}-\mathrm{O} \cdots \mathrm{H}$ interactions. Changes in the bond orders of $\mathrm{S}$ and $\mathrm{O}$ atoms of cation of IL support such observations. The predict cation-anion distances are in the range 2.30-2.60 $\AA$. The MK charge on $\mathrm{N}$ atom of cation (0.133 a.u.) is different from that observed on the IL (0.376 a.u.) in accordance to the corresponding MEP values. The frontier orbital studies predict that gap cation $(8.2152 \mathrm{eV})$ is higher than gap anion $(7.2600 \mathrm{eV})$ and, hence, the anion is the most reactive species, in agreement with the low stabilization energy calculated by NBO analysis, while the less reactive species is the cation probably due to the three long side chains. The harmonic force fields of cation and anion were calculated by using the SQMFF methodology and the complete assignments of 234 and 39 vibration modes expected for the cation and anion respectively were performed. The scaled force constants of both species were also reported. Then, the most important bands observed in the infrared and Raman spectra of IL were assigned.

\section{Supplementary Information (SI)}

Supplementary Information: Table S1-S5 and Figures S1-S8.

\section{ACKNOWLEDGEMENTS}

This work was supported with grants from financial support by The Ministry of Higher Education and Scientific Research (MESRS) of Algeria in PRFU project code: B00L01UN200120180002 and from CIUNT Project $\mathrm{N}^{\mathrm{o}}$ 26/D608 (Consejo de Investigaciones, Universidad Nacional de Tucumán). The authors would like to thank Prof. Tom Sundius for his permission to use MOLVIB. 


\section{REFERENCES}

[1] S.F. Ghasemi Gildeh, H. Roohi, M. Mehrdad, K. Rad-Moghadam, K. Ghauri, Experimental and theoretical probing of the physicochemical properties of ionic liquids composed of [Bn-DBU]+ cation and various anions, Journal of Molecular Structure 1202 (2020) 127226.

[2] M. Ahrenberg, M. Beck, C. Neise, O. Keßler, U. Kragl, S.P. Verevkin, C. Schick, Vapor pressure of ionic liquids at low temperatures from AC-chip-calorimetry, Physical Chemistry Chemical Physics 18(31) (2016) 21381-21390.

[3] L. Ni, J. Xin, K. Jiang, L. Chen, D. Yan, X. Lu, S. Zhang, One-Step Conversion of Biomass-Derived Furanics into Aromatics by Brønsted Acid Ionic Liquids at Room Temperature, ACS Sustainable Chemistry \& Engineering 6(2) (2018) 2541-2551.

[4] M. Bystrzanowska, F. Pena-Pereira, Ł. Marcinkowski, M. Tobiszewski, How green are ionic liquids? - A multicriteria decision analysis approach, Ecotoxicology and Environmental Safety 174 (2019) 455-458.

[5] B.-S. Lee, S.-T. Lin, Prediction and screening of solubility of pharmaceuticals in singleand mixed-ionic liquids using COSMO-SAC model, AIChE Journal 63(7) (2017) 3096-3104.

[6] Y. Zhou, D. Xu, L. Zhang, Y. Ma, X. Ma, J. Gao, Y. Wang, Separation of thioglycolic acid from its aqueous solution by ionic liquids: Ionic liquids selection by the COSMO-SAC model and liquid-liquid phase equilibrium, The Journal of Chemical Thermodynamics 118 (2018) 263-273.

[7] R.L. Vekariya, A review of ionic liquids: Applications towards catalytic organic transformations, Journal of Molecular Liquids 227 (2017) 44-60.

[8] J.Nawała, , B.Dawidziuk, , D.Dziedzic, , D.Gordon, , \& S. Popiel, Applications of ionic liquids in analytical chemistry with a particular emphasis on their use in solid-phase microextraction. TrAC Trends in Analytical Chemistry 105 (2018) 18-36.

[9] M. Watanabe, M.L. Thomas, S. Zhang, K. Ueno, T. Yasuda, K. Dokko, Application of Ionic Liquids to Energy Storage and Conversion Materials and Devices, Chemical Reviews 117(10) (2017) 7190-7239.

[10] Y. Qiang, S. Zhang, L. Guo, X. Zheng, B. Xiang, S. Chen, Experimental and theoretical studies of four allyl imidazolium-based ionic liquids as green inhibitors for copper corrosion in sulfuric acid, Corrosion Science 119 (2017) 68-78.

[11] G. K.Dedzo, B. B.Nguelo, I. T.Kenfack, E.Ngameni, , C. Detellier, Molecular control of the functional and spatial interlayer environment of kaolinite by the grafting of selected pyridinium ionic liquids. Applied Clay Science (2017) 143 445-451.

[12] Q. Zhou, F. Chen, W. Wu, R. Bu, W. Li, F. Yang, Reactive orange 5 removal from aqueous solution using hydroxyl ammonium ionic liquids/layered double hydroxides intercalation composites, Chemical Engineering Journal 285 (2016) 198-206.

[13] Y. Pei, Q. Lu, Y. Niu, Y. Zhao, Y. Zhao, Z. Li, H. Wang, J. Wang, Aggregation Behavior of Pyrrolidinium Ionic Liquid Surfactants in -OH-Functionalized AmmoniumBased Protic Ionic Liquids, Journal of Chemical \& Engineering Data 64(11) (2019) 47084716.

[14] C. Verma, E.E. Ebenso, M.A. Quraishi, Ionic liquids as green and sustainable corrosion inhibitors for metals and alloys: An overview, Journal of Molecular Liquids 233 (2017) 403414. 
[15] J. Cai, J. Liu, S. Mu, J. Liu, J. Hong, X. Zhou, Q. Ma, L. Shi, Corrosion Inhibition Effect of Three Imidazolium Ionic Liquids On Carbon Steel In Chloride Contaminated Environment, Int. J. Electrochem. Sci 15 (2020) 1287-1301.

[16] Fraile, J. M., García, J. I., Herrerías, C. I., Mayoral, J. A., Carrié, D., \& Vaultier, M. (2001). Enantioselective cyclopropanation reactions in ionic liquids. Tetrahedron: Asymmetry, 12(13), 1891-1894.

[17] X.-S. Lin, Y. Zou, K.-H. Zhao, T.-X. Yang, P. Halling, Z. Yang, Tetraalkylammonium ionic liquids as dual solvents-catalysts for direct synthesis of sugar fatty acid esters, Journal of Surfactants and Detergents 19(3) (2016) 511-517.

[18] C. A.Migdal, , P. E.Stott, , V. N.Bakunin, , O. P.Parenago, , G. N. Kuz'mina, , L. M.Vedeneeva, , \& A. Y. Suslov, U.S. Patent No. 6,878,676. (2005) Washington, DC: U.S. Patent and Trademark Office.

[19] A. Rout, K. Binnemans, Separation of rare earths from transition metals by liquid-liquid extraction from a molten salt hydrate to an ionic liquid phase, Dalton Transactions 43(8) (2014) 3186-3195.

[20] M. Filiz, N.A. Sayar, A.A. Sayar, Extraction of cobalt (II) from aqueous hydrochloric acid solutions into alamine 336-m-xylene mixtures, Hydrometallurgy 81(3-4) (2006) $167-$ 173.

[21] R. Banda, H.Y. Lee, M.S. Lee, Separation of Zr from Hf in hydrochloric acid solution using amine-based extractants, Industrial \& engineering chemistry research 51(28) (2012) 9652-9660.

[22] G. Naz, Z. Othaman, M. Shamsuddin, S.K. Ghoshal, Gold nanorod libraries enhancement for optical imaging, Materials Letters 166 (2016) 63-66.

[23] A. Patra, T. Mahapatra, Synthesis of tetrahydrobenzo [b] pyran derivatives catalysed by Aliquat ${ }^{\circledR} 336$ in water under microwave irradiation, Journal of Chemical Research 34(12) (2010) 689-693.

[24] M. Mateescu, I.C. Bujanca, M. Deaconu, The application of aliquat 336 as carrier in processes for wastewater treatment containing heavy metals 2017 (2017) 125-125.

[25] Assenine, M. A., Haddad, B., Paolone, A., Brandán, S. A., Villemin, D., Boumediene, M., ... \& Bresson, S. (2020). Experimental and DFT studies on structure, spectroscopic and thermal properties of N-Methyl-N, N, N-trioctylammonium chloride ionic liquid. Journal of Molecular Structure, 129625.

[26] Blanco, D., Oulego, P., Ramos, D., Fernández, B., \& Cuetos, J. M. (2017). Model-free kinetics applied to evaluate the long-term thermal stability of three [NTf2] anion-based ionic liquids. Thermochimica Acta, 656, 70-84.

[27] J.-P. Mikkola, P. Virtanen, R. Sjöholm, Aliquat 336®—a versatile and affordable cation source for an entirely new family of hydrophobic ionic liquids, Green Chemistry 8(3) (2006) 250-255.

[28] B.Haddad, D. Mokhtar, M. Goussem, E.-h. Belarbi, D. Villemin, S. Bresson, M. Rahmouni, N.R. Dhumal, H.J. Kim, J. Kiefer, Influence of methyl and propyl groups on the vibrational spectra of two imidazolium ionic liquids and their non-ionic precursors, Journal of Molecular Structure 1134 (2017) 582-590.

[29] B. Haddad, J. Kiefer, H. Brahim, E.-h. Belarbi, D. Villemin, S. Bresson, O. Abbas, M. Rahmouni, A. Paolone, O. Palumbo, Effects of C (2) methylation on thermal behavior and 
interionic interactions in imidazolium-based ionic liquids with highly symmetric anions, Applied Sciences 8(7) (2018) 1043.

[30] S.K. Panja, H. Boumediene, M. Drai, D. Villemin, S. Bresson, Probing effect of weak Hbonding on conformational change in ionic liquid: Experimental and DFT studies, Journal of Molecular Liquids 266 (2018) 727-732.

[31] B. Haddad, A. Paolone, D.Villemin, J. F.Lohier, M.Drai, S.Bresson, , ... \& E. H. Belarbi, para-Xylyl bis-1-methylimidazolium bis (trifluoromethanesulfonyl) imide: Synthesis, crystal structure, thermal stability, vibrational studies. Journal of Molecular Liquids 260(2018) 391402.

[32] S.K. Panja, B. Haddad, J. Kiefer, Clusters of the Ionic Liquid 1-Hydroxyethyl-3methylimidazolium Picrate: From Theoretical Prediction in the Gas Phase to Experimental Evidence in the Solid State, ChemPhysChem 19(22) (2018) 3061-3068.

[33] Y. Liu, C. Ma, S. Men, Y. Jin, An investigation of trioctylmethylammonium ionic liquids by X-ray photoelectron spectroscopy: The cation-anion interaction, Journal of Electron Spectroscopy and Related Phenomena 223 (2018) 79-83.

[34] B. Haddad, S. A.Brandán, A. M.Amin, A. Paolone, D.Villemin, , \& S.Bresson, Bidentate cation-anion coordination in the ionic liquid 1-ethyl-3-methylimidazolium hexafluorophosphate supported by vibrational spectra and NBO, AIM and SQMFF calculations. Journal of Molecular Structure (2020) 128104.

[35] S.Zhang, J.Wang, X.Lu, \& Q. Zhou, (Eds.). Structures and interactions of ionic liquids (Vol. 151). (2013) Springer.

[36] V. H. Paschoal, L. F. Faria, \& M. C. Ribeiro, Vibrational spectroscopy of ionic liquids. Chemical reviews, 117(10) (2017) 7053-7112.

[37] J. Kausteklis, V. Aleksa, M.A. Iramain, S.A. Brandán, Cation-anion interactions in 1buthyl-3-methyl imidazolium nitrate ionic liquid and their effect on their structural and vibrational properties, Journal of Molecular Structure 1164 (2018) 1-14.

[38] J. Kausteklis, V. Aleksa, M.A. Iramain, S.A. Brandán, DFT study and vibrational assignment of 1-Butyl-3-methylimidazolium trifluoromethanesulfonate ionic liquid by using the FT-Raman spectrum, Journal of Molecular Structure 1175 (2019) 663-676.

[39] J. W. Sprague, J. G. Grasselli, , \& W. M. Ritchey, The synthesis and infrared and nuclear magnetic resonance spectra of ammonium dicyanamide. The Journal of Physical Chemistry 68(2) (1964) 431-433.

[40] F.M. Vitucci, F. Trequattrini, O. Palumbo, J.B. Brubach, P. Roy, M.A. Navarra, S. Panero, A. Paolone, Stabilization of different conformers of bis (trifluoromethanesulfonyl) imide anion in ammonium-based ionic liquids at low temperatures, The Journal of Physical Chemistry A 118(38) (2014) 8758-8764.

[41] M.S. Miran, T. Yasuda, M.A.B.H. Susan, K. Dokko, M. Watanabe, Binary protic ionic liquid mixtures as a proton conductor: high fuel cell reaction activity and facile proton transport, The Journal of Physical Chemistry C 118(48) (2014) 27631-27639.

[42] T.A. Lima, V.H. Paschoal, L.F.O. Faria, M.C.C. Ribeiro, C. Giles, Comparing two tetraalkylammonium ionic liquids. I. Liquid phase structure, The Journal of chemical physics 144(22) (2016) 224504. 
[43] L.F.O. Faria, J.R. Matos, M.C.C. Ribeiro, Thermal analysis and Raman spectra of different phases of the ionic liquid butyltrimethylammonium bis (trifluoromethylsulfonyl) imide, The Journal of Physical Chemistry B 116(30) (2012) 9238-9245.

[44] U. Domańska, R.J.T.J.o.P.C.B. Bogel-Łukasik, Physicochemical properties and solubility of alkyl-(2-hydroxyethyl)-dimethylammonium bromide, The Journal of Physical Chemistry B 109(24) (2005) 12124-12132.

[45] O. Palumbo, F.M. Vitucci, F. Trequattrini, A. Paolone, A study of the conformers of the $\mathrm{N}, \mathrm{N}$-diethyl-N-methyl-N-propylammonium ion by means of infrared spectroscopy and DFT calculations, Vibrational Spectroscopy 80 (2015) 11-16.

[46] S. Aparicio, M. Atilhan, M. Khraisheh, R. Alcalde, Study on hydroxylammonium-based ionic liquids. I. Characterization, The Journal of Physical Chemistry B 115(43) (2011) 1247312486.

[47] E. Bodo, P. Postorino, S. Mangialardo, G. Piacente, F. Ramondo, F. Bosi, P. Ballirano, R. Caminiti, Structure of the molten salt methyl ammonium nitrate explored by experiments and theory, The Journal of Physical Chemistry B 115(45) (2011) 13149-13161.

[48] F. Capitani, C. Fasolato, S. Mangialardo, S. Signorelli, L. Gontrani, P. Postorino, Heterogeneity of propyl-ammonium nitrate solid phases obtained under high pressure, Journal of Physics and Chemistry of Solids 84 (2015) 13-16.

[49] T. Niemann, D. Zaitsau, A. Strate, A. Villinger, R. Ludwig, Cationic clustering influences the phase behaviour of ionic liquids, Scientific reports 8(1) (2018) 1-7.

[50] B. Haddad, A. Paolone, D. Villemin, M. Taqiyeddine, E.-h. Belarbi, S. Bresson, M. Rahmouni, N.R. Dhumal, H.J. Kim, J. Kiefer, Synthesis, conductivity, and vibrational spectroscopy of tetraphenylphosphonium bis (trifluoromethanesulfonyl) imide, Journal of Molecular Structure 1146 (2017) 203-212.

[51] A.B. Nielsen, A.J. Holder, GaussView, User's Reference, GAUSSIAN, Inc.: Pittsburgh, PA, USA, 2000-2003.

[52] Gaussian 09, Revision A.02, M. J. Frisch, G. W. Trucks, H. B. Schlegel, G. E. Scuseria, M. A. Robb, J. R. Cheeseman, G. Scalmani, V. Barone, B. Mennucci, G. A. Petersson, H. Nakatsuji, M. Caricato, X. Li, H. P. Hratchian, A. F. Izmaylov, J. Bloino, G. Zheng, J. L. Sonnenberg, M. Hada, M. Ehara, K. Toyota, R. Fukuda, J. Hasegawa, M. Ishida, T. Nakajima, Y. Honda, O. Kitao, H. Nakai, T. Vreven, J. A. Montgomery, Jr., J. E. Peralta, F. Ogliaro, M. Bearpark, J. J. Heyd, E. Brothers, K. N. Kudin, V. N. Staroverov, R. Kobayashi, J. Normand, K. Raghavachari, A. Rendell, J. C. Burant, S. S. Iyengar, J. Tomasi, M. Cossi, N. Rega, J. M. Millam, M. Klene, J. E. Knox, J. B. Cross, V. Bakken, C. Adamo, J. Jaramillo, R. Gomperts, R. E. Stratmann, O. Yazyev, A. J. Austin, R. Cammi, C. Pomelli, J. W. Ochterski, R. L. Martin, K. Morokuma, V. G. Zakrzewski, G. A. Voth, P. Salvador, J. J. Dannenberg, S. Dapprich, A. D. Daniels, Ö. Farkas, J. B. Foresman, J. V. Ortiz, J. Cioslowski, and D. J. Fox, Gaussian, Inc., Wallingford CT, 2009.

[53] A.D. Becke, Density-functional exchange-energy approximation with correct asymptotic behavior, Phys. Rev. A38, 1988, 3098-3100.

[54] C. Lee, W. Yang, R.G. Parr, Development of the Colle-Salvetti correlation-energy formula into a functional of the electron density. Phys. Rev. B37, 1988, 785-789.

[55] B.H. Besler, K.M. Merz Jr, P.A. Kollman, Atomic charges derived from semiempirical methods, J. Comp. Chem. 1990, 11, 431-439. 
[56] E.D. Glendening, J.K. Badenhoop, A. D. Reed, J. E. Carpenter, F. Weinhold, NBO 3.1; Theoretical Chemistry Institute, University of Wisconsin; Madison, WI, 1996.

[57] R.F.W. Bader, Atoms in Molecules, A Quantum Theory, Oxford University Press, Oxford, 1990, ISBN: 0198558651.

[58] F. Biegler-Köning, J. Schönbohm, D. Bayles. AIM2000; A Program to Analyze and Visualize Atoms in Molecules, J. Comput. Chem. 2001, 22, 545.

[59] P. Pulay, G. Fogarasi, G. Pongor, J.E. Boggs, A. Vargha, Combination of theoretical ab initio and experimental information to obtain reliable harmonic force constants. Scaled quantum mechanical (QM) force fields for glyoxal, acrolein, butadiene, formaldehyde, and ethylene. J. Am. Chem. Soc., 1983, 105, 7073.

[60] G. Rauhut, P. Pulay, Transferable Scaling Factors for Density Functional Derived Vibrational Force Fields. J. Phys. Chem. 1995, 99, 3093-3100,

[61] T. Sundius, Scaling of ab-initio force fields by MOLVIB. Vib. Spectrosc. 2002, 29, 8995.

[62] G. Keresztury, S. Holly, G. Besenyei, J. Varga, A.Y. Wang, J.R. Durig. Vibrational spectra of monothiocarbamates-II. IR and Raman spectra, vibrational assignment, conformational analysis and $a b$ initio calculations of $S$-methyl- $N, N$-dimethylthiocarbamate Spectrochim. Acta, 1993, 49A, 2007-2026.

[63] D. Michalska, R. Wysokinski, The prediction of Raman spectra of platinum(II) anticancer drugs by density functional theory, Chemical Physics Letters, 2005, 403, 211-217.

[64] R. Ditchfield, Self-consistent perturbation theory of diamagnetism. I. A gage-invariant LCAO (linear combination of atomic orbitals) method for NMR chemical shifts, Mol Phys. 1974, 27, 714-722.

[65] P. Ugliengo, MOLDRAW Program, University of Torino, Dipartimento Chimica IFM, Torino, Italy, 1998.

[66] M. Boumediene, B. Haddad, A. Paolone, M. Drai, D. Villemin, M. Rahmouni, S. Bresson, O. Abbas, Synthesis, thermal stability, vibrational spectra and conformational studies of novel dicationic meta-xylyl linked bis-1-methylimidazolium ionic liquids, Journal of Molecular Structure 1186 (2019) 68-79.

[67] B. Haddad, A.Paolone, M. Drai, M. Boumediene, D. Villemin, E. H. Belarbi, , ... \& O. Abbas, Para-xylyl linked bis-imidazolium ionic liquids: A study of the conformers of the cation and of the anion-cation hydrogen bonding. Journal of Molecular Structure 1175 (2019) $175-184$.

[68] D. Luo, J. Huang, Y. Zhang, H. Liu, P. Hu, Highly efficient separation and extraction of vanadium from a multi-impurity leachate of vanadium shale using tri-noctylmethylammonium chloride, Separation and Purification Technology 230 (2020) 115842.

[69] D. Luo, J. Huang, Y. Zhang, H. Liu, P.Hu, Efficient and environment-friendly vanadium (V) extraction from vanadium shale leachate using tri-n-octylmethylammonium chloride Sep. Purif. Technol. 2372020116482.

[70] M. Drai, A. Mostefai, A. Paolone, B. Haddad, E. Belarbi, D. Villemin, S. Bresson, O. Abbas, Y. Chaker, M. Rahmouni, Synthesis, experimental and theoretical vibrational studies of 1-methyl and 1, 2-dimethyl, 3-propyl imidazolium bis (trifluoromethanesulfonyl) imide, Journal of Chemical Sciences 129(6) (2017) 707-719. 
[71] E. Pigorsch, Spectroscopic characterisation of cationic quaternary ammonium starches, Starch-Stärke 61(3-4) (2009) 129-138.

[72] R. A. Rudyk, M.A. Checa, C. A. N. Catalán, S.A. Brandán, Structural, FT-IR, FT-Raman and ECD studies on the free base, cationic and hydrobromide species of scopolamine alkaloid, Journal of Molecular Structure 1180 (2019) 603-617.

[73] S.A. Brandán, Why morphine is a molecule chemically powerful. Their comparison with cocaine, Indian Journal of Applied Research 7(7) (2017) 511-528.

[74] S.A. Brandán, Understanding the potency of heroin against to morphine and cocaine, IJSRM, International Journal of Science And Research Methodology 12(2) (2018) 97-140. 